\title{
Assessing controls on organic matter enrichments in hemipelagic marls of the Aptian-Lower Albian Blue Marls of the Vocontian Basin (France): an unexpected variability observed from multiple “organic-rich" levels
}

\author{
Alexis Caillaud $^{1}$, Melesio Quijada ${ }^{1}$ (D), Stephan R. Hlohowskyj ${ }^{2}$, Anthony Chappaz ${ }^{2}$ (D), \\ Viviane Bout-Roumazeilles ${ }^{1}$ (D), Jean-Yves Reynaud ${ }^{1}$ (D), Armelle Riboulleau ${ }^{1}$ (D), François Baudin ${ }^{3}$ (D), \\ Thierry Adatte ${ }^{4}$, Jean-Noël Ferry ${ }^{5}$ and Nicolas Tribovillard ${ }^{1, *}$ \\ ${ }^{1}$ Université de Lille, Laboratoire d'Océanologie et Géosciences, UMR LOG CNRS-Université de Lille-ULCO, Lille, France \\ 2 STARLAB, Department of Earth and Atmospheric Sciences, Central Michigan University, Mount Pleasant, USA \\ 3 Sorbonne Universités, UPMC Univ. Paris 06, CNRS, ISTEP, 75005 Paris, France \\ ${ }^{4}$ Institute of Earth Sciences, University of Lausanne, Lausanne, Switzerland \\ 5 TOTAL S.A., CSTJF, 64000 Pau, France
}

Received: 20 October 2020 / Accepted: 3 January 2022 / Publishing online: 20 January 2022

\begin{abstract}
The Marnes Bleues Formation from the Vocontian Basin (Southeastern France) shows many dark-colored levels, some concomitant to oceanic anoxic events OAE1a (the so-called Goguel Level) and OAE1b (the Jacob, Kilian, and, above all, Paquier levels). These levels are usually referred to as being organic-rich; they are scattered through a thick, rather homogeneous, succession of marls, that is poor in organic matter (OM). Through a multi-parameter approach, the dark levels from the Aptian-Albian were characterized. Our results show that all dark levels are not OM-rich and that the dark levels exhibit variable characteristics, such as OM nature (marine $v s$. continental), sedimentation and accumulation rates, redox conditions, surface-water productivity and relative sea level, but they all show low to modest enrichments in OM. Furthermore, all the levels share in common the fact that they formed under conditions of normal to low productivity and oxic to suboxic conditions. Thus, our results strongly suggest that, in the absence of high productivity and anoxic bottom conditions, the other factors reputed to favor OM accumulation only led to sporadic and low enrichments in organic contents. It is as if such factors could only enhance OM accumulation but could not induce it alone. What was true for the Vocontian Basin may be extended to other settings, regardless of their time of deposition or location.
\end{abstract}

Keywords: organic matter / black shales / Marnes Bleues Formation / Cretaceous / productivity

Résumé - Évaluation des contrôles des enrichissements en matière organique dans les marnes homogènes hémipélagiques du Bassin Vocontien (France; Crétacé): une variabilité inattendue observée à partir de multiples niveaux « riches » en matière organique. La Formation de Marnes Bleues du Bassin Vocontien (sud-est de la France) présente de nombreux niveaux sombres, usuellement considérés comme étant riches en matière organique (MO), certains de ces niveaux sombres étant concomitants avec les événements anoxiques océaniques OAE1a (faisceau Goguel) et OAE1b (niveaux Jacob, Kilian, et surtout Paquier). Ces niveaux sombres sont dispersés au sein d'une épaisse succession d'apparence homogène de marnes, pauvres en MO. Grâce à une approche multi paramètres, les niveaux sombres de l'Aptien-Albien ont été détaillés. Nos résultats montrent que tous les niveaux sombres ne sont pas riches en MO et qu'ils présentent des caractéristiques variables, telles que la nature de la MO (marine versus continentale), les taux de sédimentation et d'accumulation, les conditions redox, la productivité de surface et le niveau relatif de la mer, mais ils montrent tous des enrichissements faibles à modestes en MO. En outre, tous les niveaux ont en commun le fait de s'être formés dans des conditions de productivité normale à faible et des conditions oxiques à suboxiques. Ainsi, nos résultats suggèrent fortement qu'en l'absence de productivité élevée et de

*Corresponding author: nicolas.tribovillard@univ-lille.fr 
conditions de fond anoxiques, les autres facteurs réputés favoriser l'accumulation de MO n'ont conduit qu'à des enrichissements sporadiques et à faibles teneurs en MO. Tout se passe comme si de tels facteurs ne pouvaient qu'améliorer l'accumulation de MO mais ne pouvaient pas l'induire à eux seuls. Ce qui était vrai pour le bassin Vocontien peut être étendu à d'autres contextes, quel que soit leur moment de dépôt ou leur localisation.

Mots clés : matière organique / schistes noirs / Marnes Bleues / Crétacé / productivité

\section{Introduction}

The Vocontian Basin (South-East of France; Fig. 1) accumulated the Marnes Bleues Formation (Blue Marls) during the Aptian-Albian. This formation is made of a thick succession of marls, deposited in a hemipelagic environment, displaying an apparently monotonous facies. Levels of dark shales (dark gray to black), sometimes rich in organic matter (OM), are interspersed in the Marnes Bleues: the Goguel, Niveau Noir, Fallot, Jacob Level, Kilian and Paquier levels (Bréhéret, 1997; Fig. 2). Some of these levels have lateral equivalents, identified in Italy in the Marche-Umbria Basin or in Switzerland, or at the scale of the entire Tethys (Bréhéret, 1997; Coccioni et al., 2006, Stein et al., 2011; Föllmi, 2012; Föllmi et al., 2012; Basilone, 2021a, 2021b). Some levels correspond to oceanic anoxic events (OAE1a or OAE1b; Schlanger and Jenkyns, 1976; Arthur et al., 1990; Jenkyns, 2010). Numerous studies have been devoted to these levels (Friès, 1987; Rubino, 1989; Tribovillard, 1989; Tribovillard and Gorin, 1991; Bréhéret, 1994, 1997; Friedrich et al., 2003; Friès and Parize, 2003; Herrle et al., 2003, 2004, 2010; Heimhofer et al., 2004, 2006; Stein et al., 2011; Westermann et al., 2013; Ando et al., 2017; Ferry, 2017; Caillaud et al., 2020). In this paper, we wish to draw up an inventory of the factors involved in the deposition of these dark levels and their enrichment in OM. The question here is whether these levels always obeyed the same determinisms, among the various factors known to favor the accumulation of $\mathrm{OM}$. We therefore examined the OM content of the sediments and the parameters of Rock-Eval pyrolysis, the grain size distribution of the carbonate-free fraction, the composition of the clay mineral assemblage, the concentrations of major and trace elements, the position of the levels rich in $\mathrm{OM}$ in a sequence stratigraphy framework, and sedimentation and accumulation rates were calculated. Finally, the question is also to know if the Aptian/Albian of the Vocontian Basin was a specific case or if the lessons learned from this study have a more general value.

\section{Geological setting of the Vocontian Basin during the Lower Cretaceous}

The South-East Basin of France corresponds to what was the slope of the northern margin of the Tethys Ocean during the Lower Cretaceous (Friès and Parize, 2003 and references therein, Figs. 1A and 1B). Thus, the Vocontian Basin was a sort of diverticulum or large gulf of the Tethys, only connected with the open ocean through its east end. A system of extensive faults and tilted blocks, inherited from the Tethyan rifting during the Jurassic times, controlled the geometry of the basin
(Graciansky and Lemoine, 1988). Then, the transition to a coupled extensive-transtensive tectonic system took place during the Aptian-Albian period (Beaudoin et al., 1986; Friès, 1987; Graciansky and Lemoine, 1988; Joseph et al., 1989). Depending on the localization in the Vocontian Basin, this structural control resulted in contrasting thickness of sediment successions.

\section{The Marnes Bleues Formation}

In the Vocontian Basin, during the Aptian-Albian period, a clastic-dominated sedimentation took place (Friès, 1987; Rubino, 1989; Bréhéret, 1997). In the deep part of the basin, the marl-dominated hemipelagic facies of the Marnes Bleues Formation (Fm.) accumulated above the Barremian/lower Aptian carbonates (Friès, 1987; Fig. 2A). A global "carbonate crisis" could explain this lithological change (Cotillon et al., 2000 and references therein). The Marnes Bleues Fm. is mainly composed of dark-grey marls with low OM contents $(0.5 \%$ on average $)$, with several occurrences of organic-rich levels (TOC $>1.5 \%)$ and some carbonate horizons (Tribovillard, 1989; Bréhéret, 1997). The mean carbonate content in the Marnes Bleues Fm. is comprised between 25\% and $35 \%$. There are also numerous deposits, like slumps, massive sandstones, turbidites, and debris-flows, mainly localized in the NW part of the Vocontian Basin (Friès, 1987, Rubino, 1989; Friès and Parize, 2003). The thickness of the entire Marnes Bleues Fm. is comprised between 650 and $800 \mathrm{~m}$ (Friès, 1987; Bréhéret, 1997), and the Aptian part is about 300-m thick. The biostratigraphic divisions were established after ammonite and foraminifer identification (Friès, 1987; Bréhéret, 1997; Dauphin, 2002). The rocks of the Marnes Bleues Fm. contain $30 \%$ to $50 \%$ of clay-sized particles $(<2 \mu \mathrm{m}$; Friès and Parize, 2003). Illite, smectite, and illitesmectite mixed-layers minerals dominate the clay mineral distribution of the terrigenous fraction.

The paleodepth was estimated to approximately $100 \mathrm{~m}$ on the platforms (Arnaud-Vanneau and Arnaud, 1991), and between 500 to $1500 \mathrm{~m}$ on the ancient slope of the margin (Guérin, 1981; Beaudoin et al. 1986; Arnaud-Vanneau and Arnaud, 1991), according to the (planktonic and benthic) foraminifer studies and the estimations deduced from the geometry of reworked deposit.

The sequence-stratigraphy framework highlights five third-order depositional sequences from the Aptian to the Lower Albian (Fig. 3; Rubino, 1989; Friès and Parize, 2003; Bréhéret, 1997; Ferry, 2017). Despite small diverging interpretations, all studies agree with the global regressive trend recorded trough these depositional sequences, highlighting the progressive closure of the Vocontian Basin during the mid-Cretaceous period. 

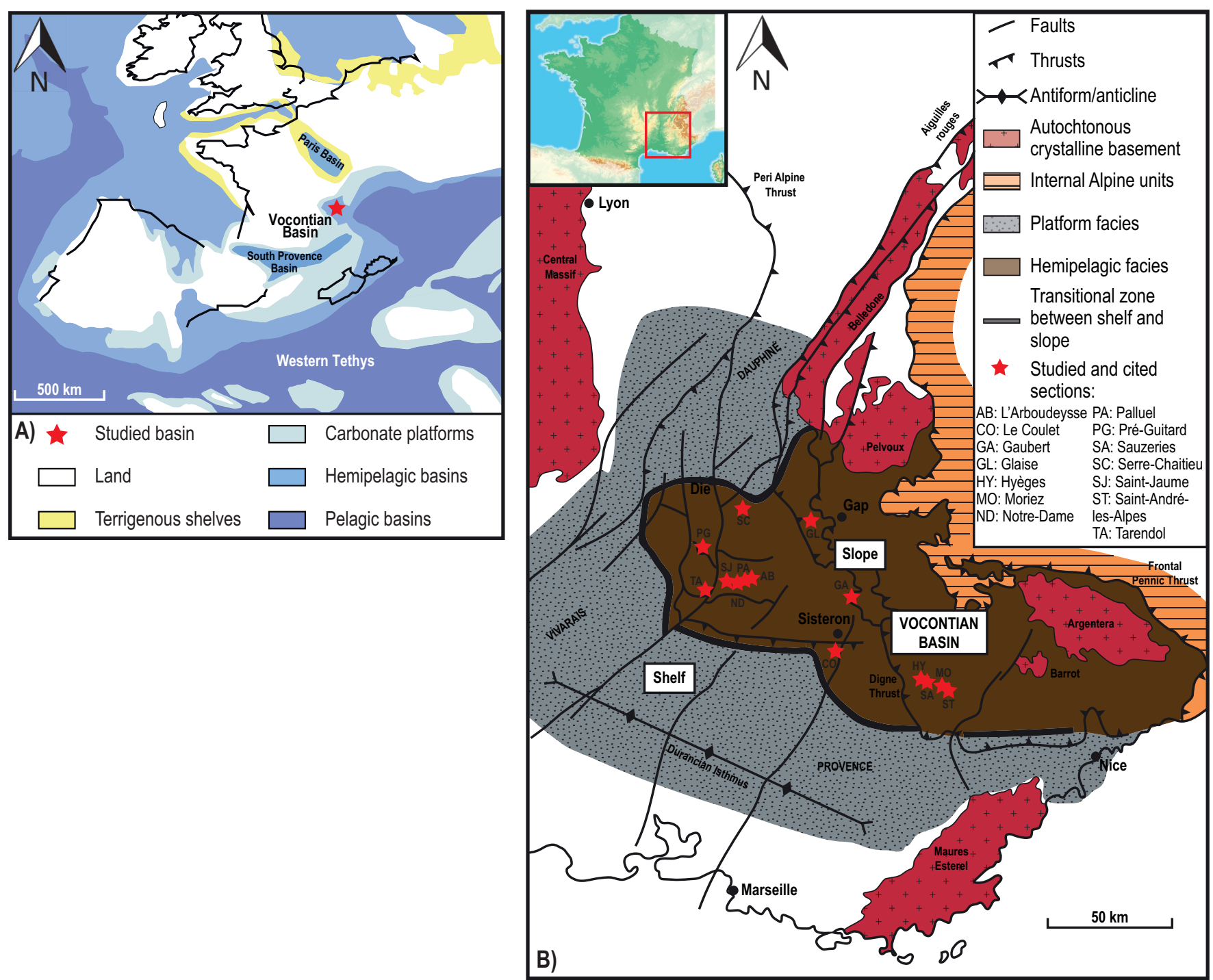

Fig. 1. (A) Aptian paleogeographical map of the western Tethys (after Stein et al., 2011, modified from Masse et al., 2000). (B) Map of the geological context of the Vocontian Basin during the Aptian times. Modified from Friès and Parize (2003).

Fig. 1. (A) Carte paléogéographique de la Téthys occidentale aptienne (d'après Stein et al., 2011, modifiée d'après Masse et al., 2000). (B) Carte du contexte géologique du Bassin Vocontien à l'Aptien. Modifié d'après Friès et Parize (2003).

\section{Dark levels within the Marnes Bleues Formation}

The Marnes Bleues Fm. composed of grey marls, shows various dark horizons, sometimes structured in paired or triple, thin, black horizons. The black horizons of the Vocontian Basin are frequently termed organic-rich levels in the literature (but we will see herein below that it is not always true); for instance, the Goguel and Paquier levels display a facies that may be termed black shale, but the other dark levels stand out of their host marls only thanks to their darker coloration. Table 1 summarizes the main features of these organic-rich levels.

\section{Materials and methods}

\subsection{Sampling and sections}

One hundred and sixty-five samples were selected from 10 sections:
Goguel Level (32 samples labeled with "-g” termination), Niveau Noir Interval (4 samples labeled with "-n" termination), Fallot Interval (21 samples labeled with "-f" termination), Jacob Level (3 samples labeled with “-j” termination), Kilian Level (2 samples labeled with “-k" termination), Paquier Level (8 samples labeled with "-p" termination), Hemipelagites - corresponding to the background marly sedimentation (62 samples labeled with "-ah" termination),

For each sample, $500 \mathrm{~g}$ to $1 \mathrm{~kg}$ of rock were sampled. To avoid any contamination by hand skin, plastic or cardboard, the rock samples were kept in aluminum foils. The studied sections are discussed in the section 4 , and they are represented on the composite type-section of the Marnes Bleues Fm. (Fig. 2A). For more details about the section locations and the references used, see Table S1. 
A. Caillaud et al:: BSGF 2022, 193, 2

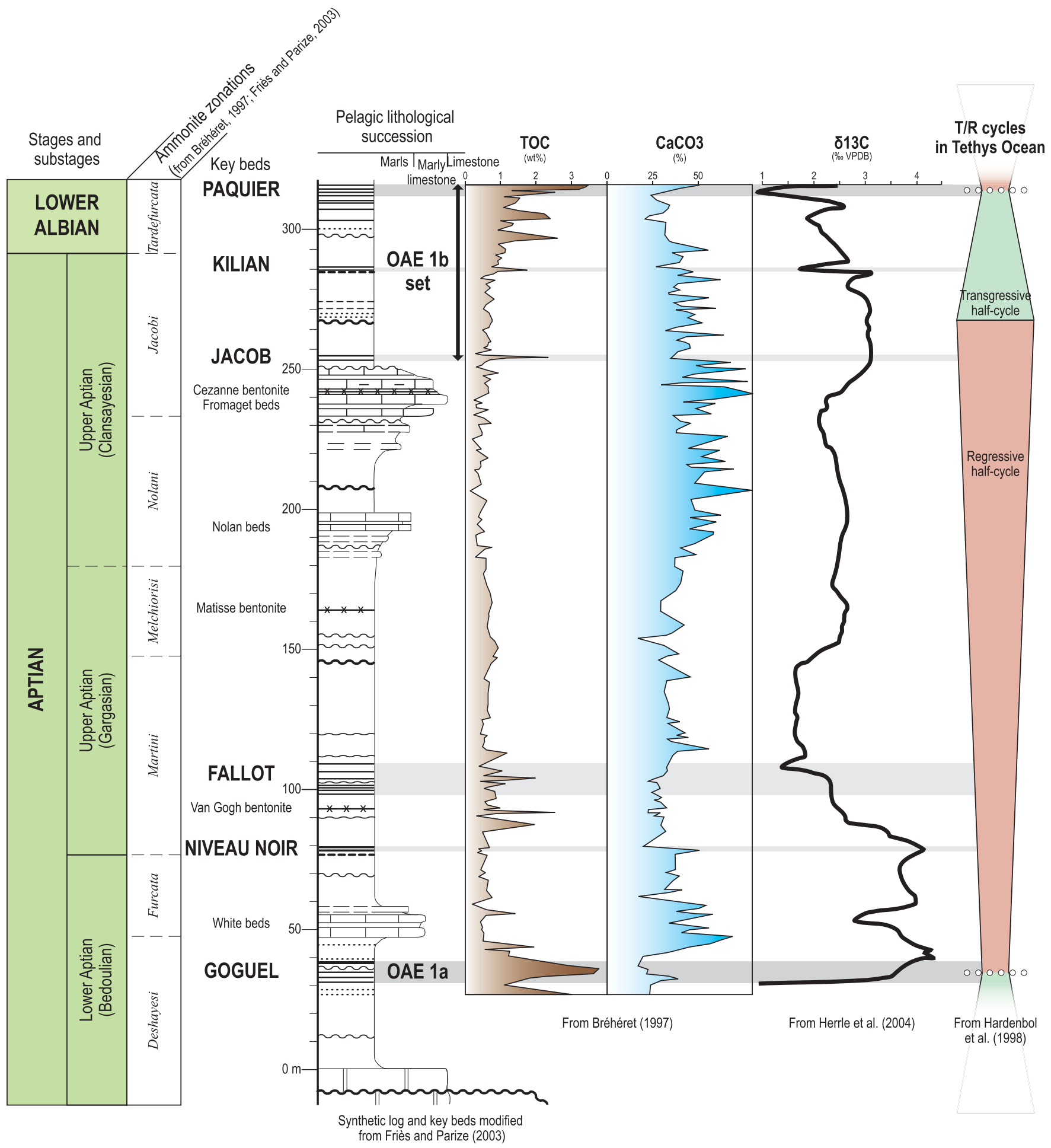

Fig. 2. Synthesis of lithology, biostratigraphy and sequence stratigraphy for the Marnes Bleues Fm. (A) Synthesis of organic and carbonate contents, stable isotope of carbon $\left(\delta^{13} \mathrm{C}\right)$, and transgressive/regressive cycles during the Marnes Bleues Fm. deposition.

Fig. 2. Synthèse de la lithologie, biostratigraphie et stratigraphie séquentielle pour les Marnes Bleues. (A) Synthèse des teneurs organiques et carbonatées, isotopes stables du carbone $\left(\delta^{13} C\right)$, et cycles transgressifs/régressifs au cours du depôt des Marnes Bleues. 
A. Caillaud et al.: BSGF 2022, 193, 2

A)

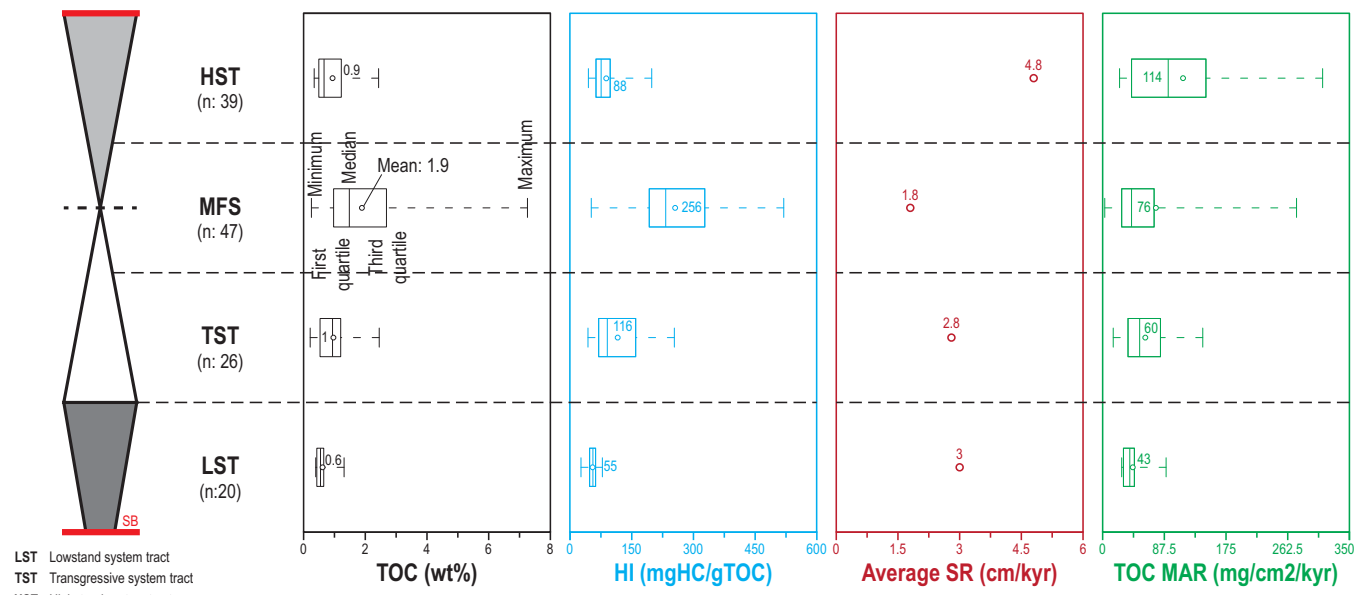

TST Transgressive system tract

HST Highstand system tract

MFS Maximum Flooding Surface

SB Sequence boundary

B)

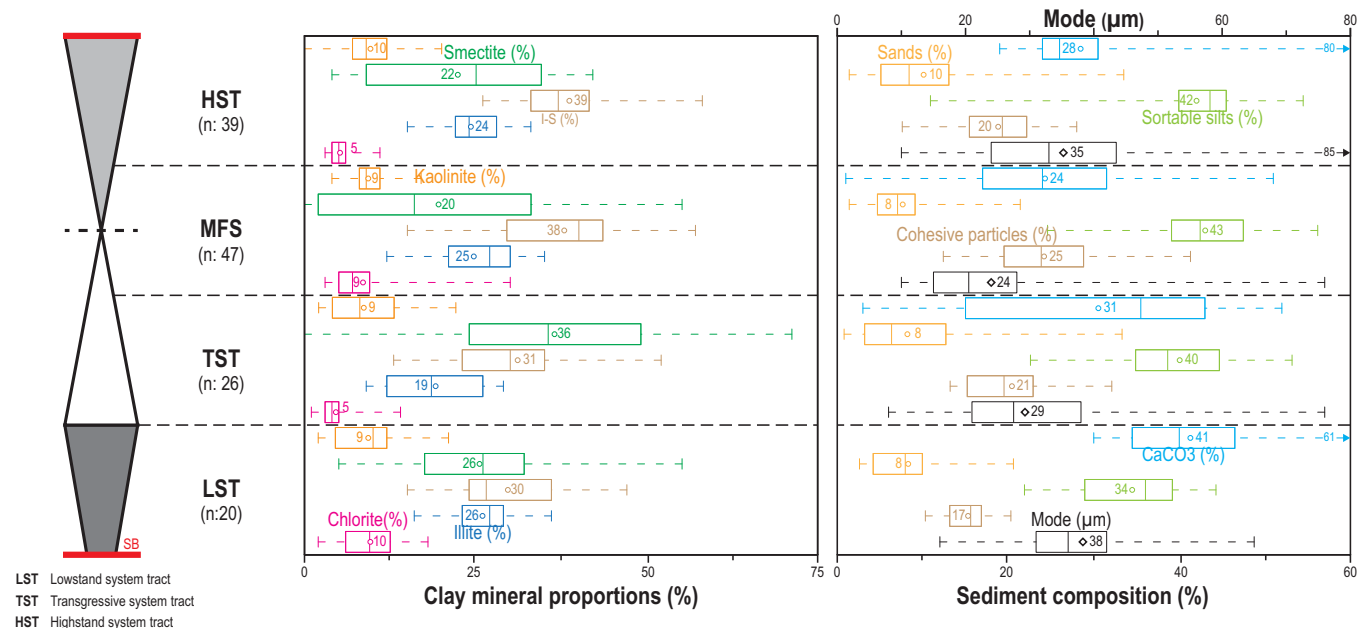

HST Highstast syse system tract

MFS Maximum Flooding Surface

SB Sequence boundary

C)
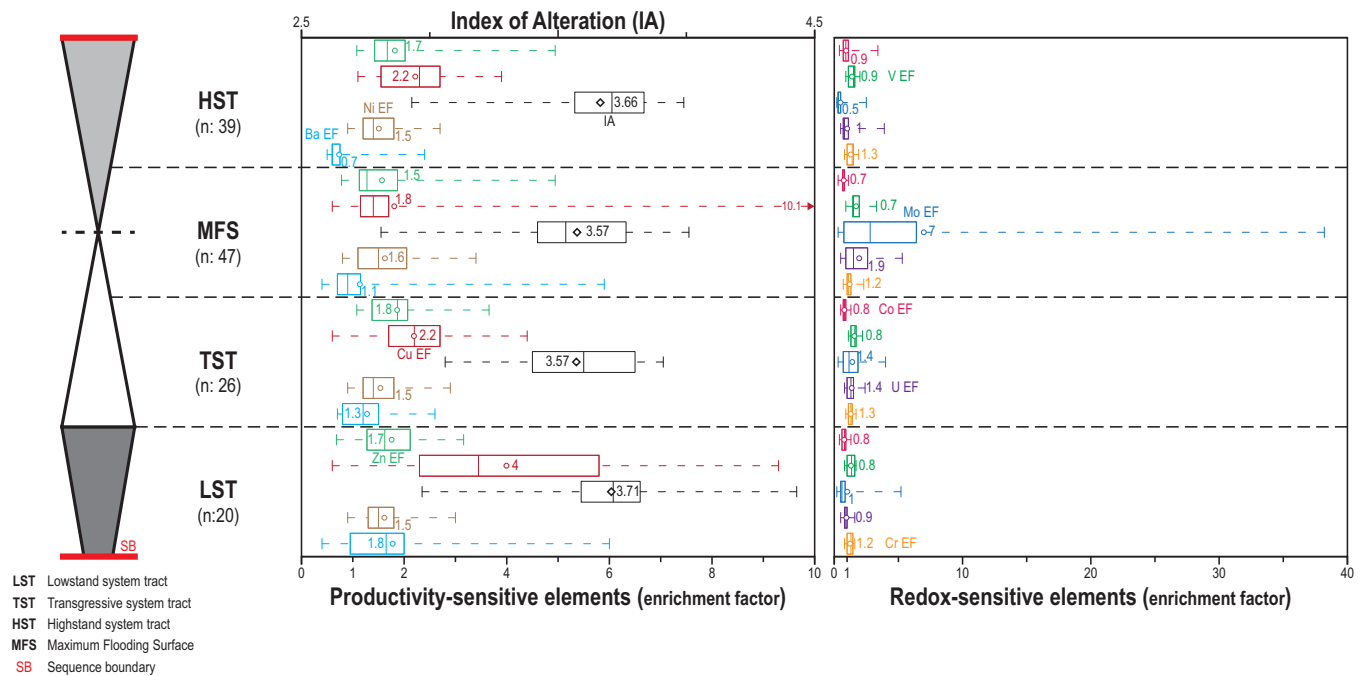

Fig. 3. Clay mineral proportion, sediment composition and grain size mode: (A) within the sequence-stratigraphy framework; and, (B) in the Aptian to Lower Albian interval and. organic-rich levels display on the type section are not at scale.

Fig. 3. Proportion de minéraux argileux, composition des sédiments et mode granulométrique: (A) dans le cadre de la stratigraphie séquentielle; et, (B) dans l'intervalle de l'Aptien à l'Albien inférieur. Les niveaux riches en MO affichés dans la section de type ne sont pas à l'échelle. 
Table 1. Descriptions of the various dark levels.

Tableau 1. Descriptions des différents niveaux riches en MO.

Organic-Rich Levels (OL) Description

The Goguel Level

The Goguel Level is made up with six horizons of dark, marly, laminated shales (GO 1 to GO 6) amounting to a thickness of about $3.4 \mathrm{~m}$ in the Sauzeries section, with each horizon being multi-cm to multi-dm thick (Bréhéret, 1997). However, the laminated horizons are often interbedded with thin turbidites in numerous locations (Friès, 1987; Bréhéret, 1997; Friès and Parize, 2003; Caillaud et al., 2020). For example, the Goguel Level reaches a thickness of $17 \mathrm{~m}$ in the Saint-Jaume section, where it is interbedded with thin turbidites and one slump. This OL records a firstly negative and then positive $\delta^{13} \mathrm{C}$ excursion in the Vocontian Basin (Herrle et al., 2004; Westermann et al., 2013), as is the case for the OAE1a in the Tethyan basins (Menegatti et al., 1998). The Goguel Level contains a total organic carbon (TOC) of 1 to $5 \mathrm{wt} \%$ with hydrogen index (HI) values up to $500 \mathrm{mgHC} / \mathrm{gTOC}$, which corresponds to Type-II kerogens, dominated by marine algal-bacterial OM (Bréhéret, 1994, 1997; Heimhofer et al., 2004, 2006; Westermann et al., 2013; Ando et al., 2017; Caillaud et al., 2020). This level was the time-equivalent of the OAE1a (Bréhéret, 1994, 1997) and, therefore, it has many equivalent levels in other basins: the Livello Selli in Italian basins, the Fischschiefer in the Lower Saxony Basin, and some other black shales in the Tethyan basins and Atlantic and Pacific Oceans (Föllmi, 2012). The astronomical calibrations allowed to determine a duration of $\sim 1.1 \mathrm{Ma}$ for the OAE1a (Malinverno et al., 2010). The Goguel Level was deposited during a major transgression recorded in the Tethys Ocean (Haq et al., 1987; Hardenbol et al., 1998), and coincided with a MFS (Rubino, 1989; pers. com. in 2017; Bréhéret, 1997) or even a "flash" transgression in the Vocontian Basin (Ferry, 2017). In the Tethyan realm, the deposition of the black shales was accounted for by intense surface-water productivity at the onset of the OAE1a (Weissert, 1990; Föllmi, 1995; Sanfourche and Baudin, 2001; Westermann et al., 2013). In the Vocontian Basin, the model was more specific: the Goguel Level was deposited during a period of sedimentary condensation (Bréhéret, 1997; Heimhofer et al., 2006) in a stratified basin (Caillaud et al., 2020), but, the efficient preservation of OM was depending on the possible occurrence of thin turbidites. Therefore, where thin turbidites were interbedded within the Goguel Level, they favored dilution and remineralization of OM, whereas where the Goguel Level was deposited without turbidites, the concentration and preservation of OM was furthered (see Caillaud et al., 2020 for details).

The Niveau Noir Interval

The Niveau Noir Interval underlines a basin-wide color change from pale to dark marlstones (Rubino, 1989). Over about $8 \mathrm{~m}$ in the Saint-Jaume section, this interval is composed of one pair of dark marly shale horizons and three pairs of slightly lesser dark marly shale beds (NN1 to NN4, Bréhéret, 1997) interbedded within grey marlstones. In the Vocontian Basin, this OL coincides with a positive $\delta^{13} \mathrm{C}$ excursion (Herrle et al., 2004,) and its duration was estimated to ca. $300 \mathrm{kyr}$ using cyclostratigraphy (Dauphin, 2002). The Niveau Noir Interval is termed "black shales" or "organic-rich level" in the literature (Herrle et al., 2003, 2010; Föllmi, 2012; Ghirardi et al., 2014); however TOC contents are comprised between 0.7 and $1.2 \mathrm{wt} \%$ only (Bréhéret, 1997). This interval shows very low HI (<100 mgHC/gTOC), corresponding to Type-III kerogens (terrestrial or degraded OM). The Niveau Noir Interval was deposited at a 3rd-order MFS (Rubino, 1989; Friès and Parize, 2003) and was ascribed the "productivity-driven model" by Herrle et al. (2010). This model involves a period of strong surface-water productivity and evaporation, enhancing oxygen depletion in the deep basin and therefore the establishment of a water-column stratification (based on a study of calcareous nannofossil, Herrle et al., 2010).

The Fallot Level

Throughout an interval of about $21 \mathrm{~m}$ in the Serre-Chaitieu section, the Fallot Interval corresponds to numerous bundles of two or three horizons each (FA 1 to FA 4, Bréhéret, 1997) of dark marlstones within grey marlstones, with multi-cm to m thickness for each bundle (Bréhéret, 1997, Dauphin, 2002, Friedrich et al., 2003). Based on astronomical calibration performed on the Piobbico core in Central Italy, the duration of the Fallot Interval was estimated to be $\sim 360 \mathrm{kyr}$ (Huang et al., 2010), that is, very close to the duration of $\sim 350 \mathrm{kyr}$ proposed by Friedrich et al. (2003). TOC values are ranging between 1 to $2 \mathrm{wt} \%$ and HI values are highly variable (Bréhéret, 1997). Thus, the kerogen-type varies according to each bundle of horizons: Type-II, II-III or III: according to Rock-Eval data, the origin of OM is mixed. At the top of the Fallot Interval, a negative $\delta^{13} \mathrm{C}$ excursion is observed in the Vocontian Basin (Herrle et al., 2004), which can be correlated with other levels in Tethyan basins ("Livello Renz", Coccioni et al., 2006) and in the Atlantic and Pacific Oceans ("Tahlmann" black shales, Herrle et al., 2003). The Fallot Interval was deposited during a HST (Rubino, 1989; Friès and Parize, 2003). Based on foraminifera, palynomorphs, and kerogen data, two depositional models were proposed by Friedrich et al. (2003). Some of bundles were formed by the "productivity-driven model" (see above) and show Type-II kerogens (marine OM). The other bundles correspond to the "preservation-driven model", which implies a limited renewal of bottom-water in the basin coupled to an increase of continental runoff and fresh water inputs. Consequently, a water-column stratification developed in the Vocontian Basin, favoring the formation of dysoxic bottom-waters.

Page 6 of 22 
Table 1. (continued).

\begin{tabular}{|c|c|}
\hline Organic-Rich Levels (OL) & Description \\
\hline
\end{tabular}

The Kilian Level

The Paquier Level
The Kilian Level is present as a $80 \mathrm{~cm}$-thick horizon of dark marly shales within grey marlstones in the Tarendol section (Bréhéret, 1997). The TOC can reach up to $3 \mathrm{wt} \%$ with very low HI values $(\sim 100 \mathrm{mgHC} /$ gTOC), corresponding to a terrestrial origin of the OM (Type-III kerogen; Bréhéret, 1994, 1997).

According to astronomical calibration, the duration of this thin horizon was estimated to be of ca. $120 \mathrm{kyr}$ (Huang et al., 2010). In the Vocontian Basin, the Kilian Level corresponds to a strong negative $\delta^{13} \mathrm{C}$ excursion (Herrle et al., 2004). There are some equivalents of this level, sometimes also called "Kilian Level" in the Umbria-Marche Basin and Central Atlantic (Sabatino et al., 2015, 2018). The depositional model proposed by Herrle et al. (2003) is very close to the "preservation-driven model". On account of a monsoon-type forcing, enhanced warm and humid conditions implied increased fresh-water inputs into the Vocontian Basin, and, as a result, the reduction of bottom-water ventilation (Herrle et al., 2003). The Kilian Level was formed during a TST (Rubino, 1989; pers. com. in 2017).

The Paquier Level consists of dark, marly, laminated shales, $1.6 \mathrm{~m}$-thick, within dark marlstones in the L'Arboudeysse section (Herrle et al., 2003). This OL is observed in numerous locations with an equal thickness (Bréhéret, 1997). TOC values are ranging between 3 to $8 \mathrm{wt} \%$, with $\mathrm{HI}$ values up to $500 \mathrm{mgHC} /$ gTOC (Tribovillard, 1989; Bréhéret, 1994, 1997). Type-II kerogens indicate a marine OM, however, palynofacies observation put forward the significant contribution of terrestrial OM (Tribovillard and Gorin, 1991). In the Vocontian Basin, this OL coincides with a strong negative $\delta^{13} \mathrm{C}$ excursion (Herrle et al., 2004,) and it was estimated to have a ca. $44 \mathrm{kyr}$ duration (Huang et al., 2010). The Paquier Level corresponds to the "Livello Urbino" in the Umbria-Marche Basin, and has equivalents in the Central and North Atlantic (Coccioni et al., 2006; Föllmi, 2012). In the Vocontian Basin, the Paquier Level was interpreted as a 3rd order MFS (Rubino, 1989; Friès and Parize, 2003), and, at larger scale, it was contemporaneous of a major transgression in the Tethyan realm (Haq et al., 1987; Hardenbol et al., 1998). Moreover, it was deposited during a period of warm and humid conditions with strong fresh-water inputs into the basin. These conditions were similar to those interpreted for the Jacob and Kilian Levels ("preservation-driven model"; OAE1b), but they were more intense and led to anoxic conditions in the deep basin (Tribovillard and Gorin, 1991; Bréhéret, 1997; Erbacher et al., 2001; Herrle et al., 2003; Ando et al., 2017). Owing to strong continental-water inputs that have furthered nutrient inputs, surface productivity increased in the basin. 


\subsection{Grain-size analysis}

Grain-size analysis was performed on 161 samples from the carbonate-free fraction using a Malvern Mastersize $2000^{\circledR}$ laser diffractometer at the Laboratoire d'Océanologie et de Géosciences of the Lille University, following the classical protocol detailed in Trentesaux et al. (2001). Precision is about $5 \%$ (Sperazza et al., 2004), but for the finest sizes $(<5 \mu \mathrm{m})$, the apparatus is slightly less accurate, according to the manufacturer. The grain-size sorting is the following: cohesive particles, including the clay and the finer silt $(<10 \mu \mathrm{m})$; sortable silt or non-cohesive silt $(10-63 \mu \mathrm{m})$; and sand (63$2000 \mu \mathrm{m})$. We considered the fraction below $10 \mu \mathrm{m}$ as cohesive particles, because of the accuracy of the apparatus for the fine grain sizes $(<5 \mu \mathrm{m})$. The analyses were performed on the terrigenous fraction (after acid digestion) and then converted into the bulk sediment composition. Moreover, according to McCave et al. (1995), the silt size range (2$63 \mu \mathrm{m}$ ) must be subdivided due to the "mechanical" behavior of particles. Thus, silts thinner than $10 \mu \mathrm{m}$ have the same behavior as that of clays (cohesive particles) whereas silts coarser than $10 \mu \mathrm{m}$ (sortable silts) behave as non-cohesive particles. In the present study, the coarser silts are used as current strength indicators (McCave et al., 1995).

\subsection{Clay minerals}

In the $<2 \mu \mathrm{m}$ terrigenous fraction, the clay assemblages have been determined on 155 samples with the standard protocol of the X-Ray Diffraction (Bout-Roumazeilles et al., 1999; Riboulleau et al., 2014), using a Bruker D4 Endeavour apparatus in the Laboratoire d'Océanologie et de Géosciences, Lille University. The relative error margin of the semi-quantitative estimation is $\pm 5 \%$ (Bout-Roumazeilles et al., 1999).

\subsection{Rock-Eval}

Rock-Eval pyrolysis of 165 samples were performed using a Rock-Eval $6^{\mathbb{R}}$ apparatus (see Behar et al., 2001 for details) at the Sorbonne University (ISTeP, Paris). Total organic carbon contents (TOC, wt $\%$ ), hydrogen index (HI, $\mathrm{mgHC} / \mathrm{gTOC}$ ), oxygen Index $\left(\mathrm{OI}, \mathrm{mgCO}_{2} / \mathrm{gTOC}\right)$ and $\operatorname{Tmax}\left({ }^{\circ} \mathrm{C}\right)$ were determined. According to Espitalié (1993), Rock-Eval pyrolysis allows typifying the type and thermal maturity of kerogens. Keeping in mind that the carbonate fraction of the Marnes Bleues Fm. is mainly composed of calcite (Bréhéret, 1997), total carbonate content $\left(\mathrm{CaCO}_{3}\right.$, wt \%) has been calculated from the Rock-Eval MinC (\%) with the formula: $\mathrm{CaCO}_{3} \quad(\%)=7.976 \times \mathrm{MinC}(\%)$. To the best of our knowledge, the TOC data available in the literature consulted about the Vocontian Basin were also measured using RockEval pyrolysis.

\subsection{Elemental analysis}

Determination of the contents in major and trace elements was performed at the University of Lausanne (ISTE-UNIL laboratory) using X-ray fluorescence (XRF) spectrometry, according to the protocol detailed in Montero-Serrano et al.
(2015). Detection limits were $<0.01 \mathrm{wt} \%$ for major elements and between 1 and $5 \mathrm{ppm}$ for trace elements. The accuracy of analysis was checked by analysis of standard reference materials.

For the Notre-Dame (pro parte), Glaise (pro parte), SaintJaume, Serre-Chaitieu and Tarendol sections (92 samples), major and traces element analysis was performed at STARLAB Laboratory (Central Michigan University). The elements were analyzed by inductively coupled plasma mass spectrometry (ICP-MS), using external calibration (Babos et al., 2019). Analytical precision based on replicate analyses was better than $8 \%$ and detection limits were $<1 \mathrm{ppb}$ for the major elements and $<40 \mathrm{ppt}$ for the trace elements.

Enrichments factors (EFs) were calculated using the following formula:

$$
\mathrm{X}_{\mathrm{EF}}=(\mathrm{X} / \mathrm{Al})_{\text {sample }} /(\mathrm{X} / \mathrm{Al})_{\text {upper crust }},
$$

where $\mathrm{X}$ and $\mathrm{Al}$ are the concentrations of element $\mathrm{X}$ and aluminum (wt \%). Enrichment factors are normalized using the elemental upper crust concentrations of McLennan (2001), and, to minimize the effects of dilution by carbonate or biogenic silica, the aluminum normalization is commonly used (see Tribovillard et al., 2006 for explanations and limits). For example, an EF equal or close to 1 indicates that the sample has a concentration equal to the element concentration in the upper crust. A significant enrichment of an element over average upper crustal concentrations corresponds to $\mathrm{EF}>3$, while moderate to strong enrichments correspond to an $\mathrm{EF}>10$ (Algeo and Tribovillard, 2009).

A chemical weathering index, the Index of Alteration (IA), was calculated. The IA is equivalent to the Chemical Index of Alteration (CIA, Nesbitt and Young, 1982), and may be used in case of carbonate-rich sediments ( $>30 \%$ carbonates), as the CIA may lead to misleading interpretations (Goldberg and Humayun, 2010). IA $=\mathrm{LN}\left(\mathrm{Al}_{2} \mathrm{O}_{3} / \mathrm{Na}_{2} \mathrm{O}\right)$, in molar proportions. This index avoids uncertainties concerning the necessary corrections caused by the presence of non-silicate phases, in particular, the carbonate and phosphate phases (Von Eynatten et al., 2003). Increased IA values can be interpreted as reflecting more intense chemical weathering over emerged lands, source areas of the clastic fraction.

\subsection{Average Sedimentation Rate (SR) and Total Organic Carbon Mass Accumulation Rates (TOC MARs)}

Previous works calculated an average sedimentation rate (SR) in the Upper Aptian of about $3 \mathrm{~cm} / \mathrm{kyr}$, regardless of the compaction rates (Kößler et al., 2001; Heimhofer et al., 2004). This average SR was used for most of the samples corresponding to the background hemipelagites in the present study. For the organic-rich levels, the average SR were specifically calculated with the following formula: average SR $(\mathrm{cm} / \mathrm{kyr})=$ thickness/duration of the organic-rich levels, where thickness was measured in cm (Bréhéret, 1997; Dauphin, 2002; Herrle et al., 2003; Heimhofer et al., 2006; Stein et al., 2011; Westermann et al., 2013) and duration was estimated from orbital calibrations in kyr (Kößler et al., 2001; Huang et al., 2010; Malinverno et al., 2010; see Table S3). For the 


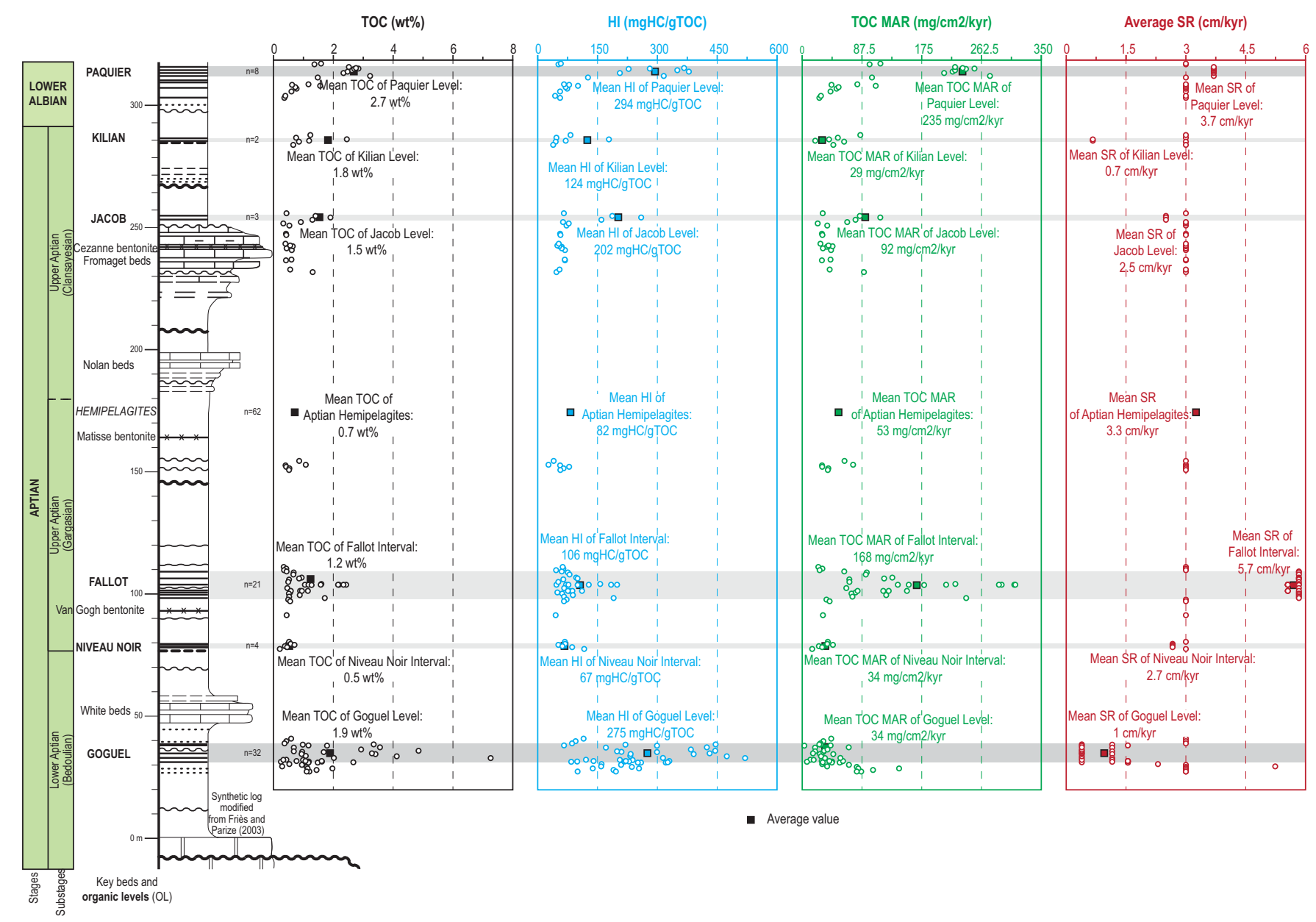

Fig. 4. TOC, HI, SRs and TOC MARs: (A) within the sequence-stratigraphy framework; and, (B) in the Aptian to Lower Albian interval. Fig. 4. TOC, HI, SR et TOC MAR: (A) dans le cadre de la stratigraphie séquentielle; et (B) dans l'intervalle de l'Aptien à l'Albien inférieur.

Notre-Dame section, where the top of the Goguel Level is not observed (Friès and Parize, 2003) and, for the Baudinard section, for which no calibration data are available, sedimentation rates could not be calculated.

To evaluate the variations of organic carbon inputs, the TOC mass accumulation rate (TOC MAR) can be calculated using the following formula from Westermann et al. (2013):

TOC MAR $\left(\mathrm{mg} / \mathrm{cm}^{2} / \mathrm{kyr}\right)=($ TOC $(\mathrm{wt} \%) \times$ rock density $\left(\mathrm{g} / \mathrm{cm}^{3}\right) \times$ average SR $\left.(\mathrm{cm} / \mathrm{kyr})\right) \times 10$, where TOC values come from Rock-Eval data, the rock density is $2.3 \mathrm{~g} / \mathrm{cm}^{3}$ for marlstones, $2.4 \mathrm{~g} / \mathrm{cm}^{3}$ for siltstones and $2.7 \mathrm{~g} / \mathrm{cm}^{3}$ for marly limestones and limestones (Attewell and Farmer, 1976; marlstones if $\mathrm{CaCO}_{3}>35 \%$, marly limestones and limestones if $\mathrm{CaCO}_{3}>65 \%$ in this study).

Organic matter dilution by clastic materials in the dark levels was calculated according to data available in previous works (Tribovillard and Gorin, 1991; Bréhéret, 1997; Heimhofer et al., 2004; Ando et al., 2017). The TOC, thickness, and duration of each dark level are available in Table S4. It is important to precise that the aim of calculating these accumulation rates (average SR and TOC MAR) is to inter-compare the sections. Direct comparison with accumulation rates of modern environments or other geological formations is not recommended because compaction rates are not considered here in the average SR calculation.

\section{Results}

The results are presented in Tables S3 and S5-S9. In order to facilitate data screening, the main results associated to the average values within the dark levels and background hemipelagites, are shown in Figures 5 and 6. Box-plot diagrams are used to compare the samples according to their positions in the sequence stratigraphy framework (Fig. 3).

\subsection{Sediment characteristics}

The mode of the grain-size distribution curves (clastic fraction of the rock) ranges from 8 to $85 \mu \mathrm{m}$ (Table S5). The dark levels exhibit an average mode slightly lower (20 to $26 \mu \mathrm{m})$ than that of the hemipelagites $(32 \mu \mathrm{m})$, except for the Fallot Interval (42 $\mu \mathrm{m}$; Figs. 3 and 4). Sediments are mainly composed of siltstones (carbonate content $<35 \%$ ) and marlstones (carbonate content $>35 \%$; Table S5). The distribution of particle sizes follows a unimodal normal 
distribution. The proportions of cohesive particles are lower in the hemipelagites with Fallot Interval and Paquier Level displaying lower values $(19,18$, and $17 \%$ on average, respectively) than the other dark levels ( 23 to $26 \%$, Figs. 3 and 4). The proportions of sortable silts are similar or slightly lower for the hemipelagites (38\%), compared to the dark levels (39 to $44 \%$ ). The average proportions of sands are lower than $10 \%$ in both hemipelagites and dark levels, except for the Fallot Interval (14\%; Figs. 3 and 4). Carbonate contents show significant variations (21 to $35 \%$ ), with a gradual increase of the $\mathrm{CaCO}_{3}$ proportion (also previously mentioned by Bréhéret, 1997).

The comparison of the system tracts and MFS displays slightly higher average modes in the LST and HST (38 and $35 \mu \mathrm{m}$, respectively) than in the TST and MFS ( 29 and $24 \mu \mathrm{m}$, respectively). Similarly, the samples corresponding to TST and MFS show weakly higher proportions of cohesive particles (21 and $25 \%$ on average) than the LST samples (17\%, Figs. 3 and 4$)$, while the average proportion of cohesive particles in the HST is $20 \%$. The LST exhibits the lowest average proportions of sortable silts $(34 \%)$, coupled to the highest proportions of carbonates $(41 \%)$. On the contrary, the average proportions of sortable silts are dominant in the TST, MFS, and HST (40 to $43 \%)$. The MFS and HST exhibit slightly lower carbonate content (24 and $28 \%$ ) than the TST (31\%).

\subsection{Clay minerals}

The distribution of clay minerals is dominated by illitesmectite mixed-layer minerals (I-S R1, with smectite layers amounting to less than $40 \%$ ), illite, and smectite (I-S R0 with smectite layers making up to $70-90 \%$ of the edifice), in decreasing proportions (Table S5). The clay-mineral assemblages also display subordinate proportions of chlorite and kaolinite, and the ratio of these two minerals fluctuates according to orbital parameters (Ghirardi et al., 2014). Let us remind that kaolinite is generally a good indicator of variations in the hydrological cycle, an important factor for understanding the deposition of OM-rich levels (e.g., Corentin et al., 2020). The Goguel, Kilian, Niveau Noir and Fallot levels and hemipelagites show high average contents of I-S, ranging from 32 to $42 \%$. In these groups of samples, average smectite contents are fluctuating from $10 \%$ in the Niveau Noir Interval to $30 \%$ in the hemipelagites, while the Goguel Level is devoid of smectite in the Sauzeries section (Table S6; this is expected, the section being in the deeply buried part of the basin; see Caillaud et al., 2020). The clay assemblages of the Jacob and Paquier levels are dominated by smectite (44 and $42 \%$ on average, respectively), with significant I-S contents (24 and $28 \%$ ). The average illite proportions range from $14 \%$, in the Paquier Level, to $31 \%$, in the Niveau Noir Interval, with a value of $23 \%$ in the hemipelagites. Kaolinite and chlorite are present in minor abundance $(<15 \%$ on average), except for the Kilian Level (kaolinite content of $18 \%$ on average). Through the Aptian to Lower Albian interval, two main variations are observed in the clay assemblage: (1) smectite gradually increases (although the Kilian Level exhibits a local decrease in smectite contents, the caging sediments show high contents); and (2) I-S and illite gradually decrease upward. To a lesser extent, the kaolinite content weakly increases.

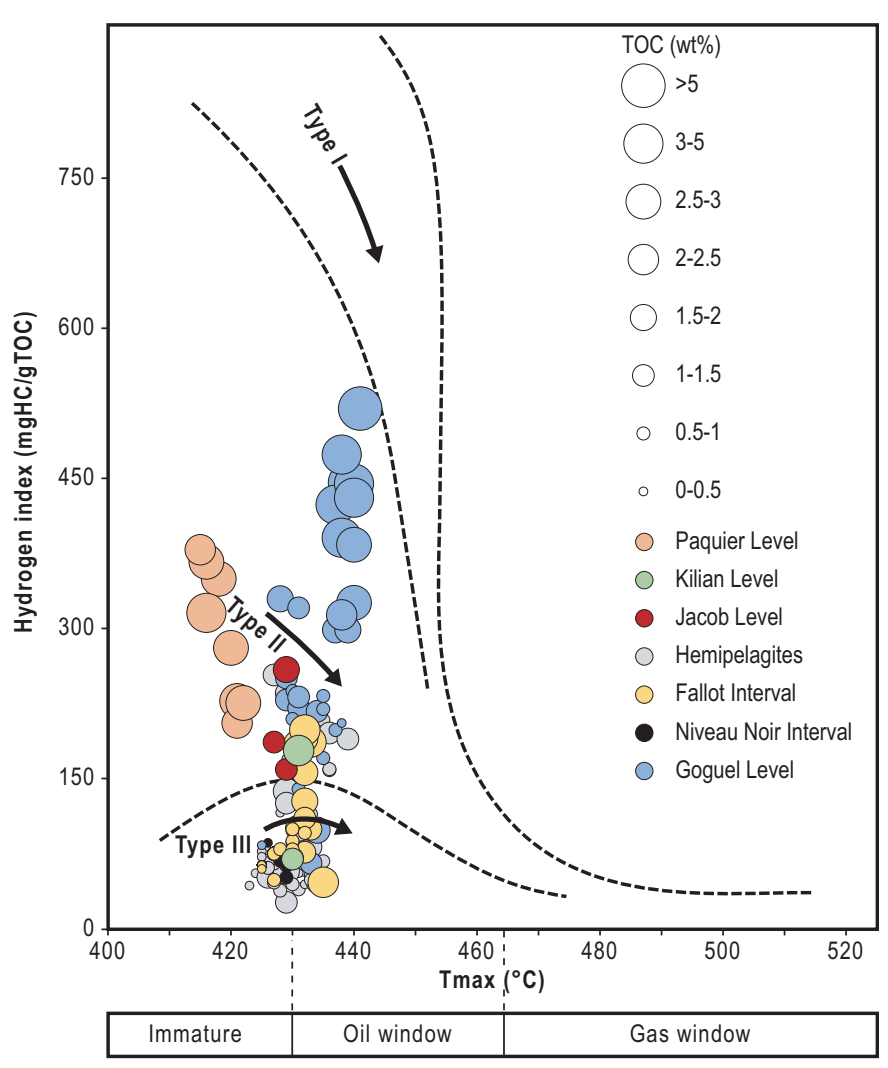

Fig. 5. Pseudo Van-Krevelen diagram (Espitalié et al., 1985) showing the typology of the OM for the studied samples.

Fig. 5. Pseudo diagramme de Van-Krevelen (Espitalié et al., 1985) montrant la typologie de la MO pour les échantillons étudiés.

Box-plot diagrams show some specificity in the distribution of the main clay minerals (Figs. 3 and 4). The smectite contents are higher in the LST and TST (26 and 36\% on average, respectively) than in the MFS and HST (20 and 22\%). The I-S contents progressively increase from the LST to the HST (30 to 39\%). The TST shows slightly lower illite proportions $(19 \%)$ than the other groups (24 to $26 \%$ ).

\subsection{Bulk organic matter}

The total organic carbon (TOC) content displays values ranging from 0.2 to $2.7 \mathrm{wt} \%$ (Tables $\mathrm{S} 2$ and $\mathrm{S} 7$ ). The hemipelagites show low TOC values $(0.2$ to $2.0 \mathrm{wt} \% ; 0.7 \mathrm{wt} \%$ on average), while the average TOC value of the dark levels (Fig. 5) indicates poor to moderate OM enrichments, ranging from $0.5 \mathrm{wt} \%$ in the Niveau Noir Interval to $2.7 \mathrm{wt} \%$ in the Paquier Level (see Table S2 for average TOCs and extreme values). The highest $\mathrm{HI}$ values are observed in the Goguel (275 mgHC/gTOC on average) and Paquier levels (294 mgHC/ gTOC), and the other groups of samples indicate low to very low average $\mathrm{HI}$ values (67 to $202 \mathrm{mgHC} / \mathrm{gTOC}$ ). Tmax values are variable according to the position of sections in the Vocontian Basin, ranging from $415^{\circ} \mathrm{C}$ to $441^{\circ} \mathrm{C}$. Because almost all the samples (131/132) display a TOC $>0.3 \mathrm{wt} \%$, the $\mathrm{HI}$ and Tmax parameters could be interpreted in a pseudo Van- 
Krevelen diagram (Fig. 5, Espitalié et al., 1985). Thus, the Tmax values indicate immature to oil-window stages for the kerogens. The various types of kerogens suggest various origins of the $\mathrm{OM}$ in the Marnes Bleues Fm. corresponding to marine OM (Type-II kerogens), mixed marine or terrestrial OM (Type-II-III kerogens), and terrestrial or degraded marineOM (Type-III kerogens) (see details for each group of samples in Table S2). Here, the LST and HST show (very) low average TOC (0.6 and $0.9 \mathrm{wt} \%$, respectively) and $\mathrm{HI}$ values (55 and $88 \mathrm{mgHC} / \mathrm{gTOC}$ ), while the TST displays low average TOC $(1 \mathrm{wt} \%)$ and $\mathrm{HI}(116 \mathrm{mgHC} / \mathrm{gTOC})$. The samples of MFS show the highest average TOC and HI values $(1.9 \mathrm{wt} \%$ and $256 \mathrm{mgHC} / \mathrm{gTOC})$.

\subsection{Inorganic geochemistry}

Elemental concentrations and enrichment factors (EFs) are reported in Tables S8 and S9. For the Marnes Bleues Fm., the $\mathrm{Fe} / \mathrm{Al}$ ratio is ranging from 0.29 to 1.16 , but the average ratios are approximately similar, for each dark level (0.42 to 0.45$)$, except for the Kilian Level (0.35). These average ratios are close to the average crustal value (0.44, McLennan, 2001). The $\mathrm{Ti} / \mathrm{Al}$ ratios were calculated to detect a possible excess of titanium compared to aluminum, another useful detrital elemental proxy (Tribovillard et al., 2006). The Ti/Al ratios range from 0.04 to 0.07 (Table S9), which is quite close to the average crustal value. The productivity-sensitive elements $(\mathrm{Ba}$, $\mathrm{Cu}, \mathrm{Ni}$ ) show a homogeneous distribution throughout the Aptian to Lower Albian interval. Average Ba EFs, Cu EFs and Ni EFs display ranges from 0.6 to $1.6,1.5$ to 4 , and 1.5 to 2.5, respectively. The only significant (yet low) enrichment factors $(\mathrm{EF}>3)$ are observed for the average $\mathrm{Cu}$ EFs in the Kilian Level (3) and in the Niveau Noir Interval (4).

The values of the index of alteration (IA) gradually increase through the stratigraphic interval studied (Fig. 4). In the lower part of the type section, most of the samples show an IA of 3.6, while in the upper part, the samples display an IA of $\sim 3.8$, which is a significant (but modest) variation, regarding this index.

The redox-sensitive elements do not show important variations, except for molybdenum (Fig. 4). The highest Mo EF values were recorded in the Paquier and Jacob levels (22 and 9 on average, respectively), and, to a lesser extent, the Goguel Level ( 2 on average, but 5 on average in the Sauzeries section, which is not much). In the other groups of samples, the average Mo EFs range from 0.4 to 2.3 (that is, no significant enrichment). Uranium displays a weak enrichment in the Paquier Level $(\mathrm{EF}=3.8$ on average), but it exhibits almost invariant EFs in the other groups of samples (0.8 to 1.7). The average $\mathrm{EFs}$ of $\mathrm{Co}, \mathrm{Cr}$, and $\mathrm{V}$, do not show any significant enrichment, neither in the dark levels nor in the hemipelagites $(0.7-0.9,1-1.3,1.2-2.1)$.

\subsection{Average Sedimentation Rate (SR) and Total Organic Carbon Accumulation Rates (TOC MARs)}

The average SRs values range from 0.4 to $5.8 \mathrm{~cm} / \mathrm{kyr}$. The hemipelagites show an average SR value of $3.3 \mathrm{~cm} / \mathrm{kyr}$, and only the Paquier Level and the Fallot Interval exhibit a higher average SR (Table S2; Fig. 6), while the Jacob Level and the
Niveau Noir Interval display a slightly lower average SR than the hemipelagites. The Kilian and the Goguel levels yield low average SRs.

The TOC MARs show variable values ( 3 to $312 \mathrm{mg} / \mathrm{cm}^{2} / \mathrm{kyr}$, average values in Table S3): (1) low average TOC MARs in the Goguel Level, Niveau Noir Interval, hemipelagites and Kilian Level (Table S2); (2) moderate average TOC MAR in the Jacob Level (Table S2); and, 3) high average TOC MARs in the Fallot Interval and Paquier Level (Table S2). The LST and TST exhibit moderate average SRs $(2.8-3 \mathrm{~cm} / \mathrm{kyr})$, whereas the HST shows the highest average SR $(4.8 \mathrm{~cm} / \mathrm{kyr})$. The MFS samples correspond to low average SR $(1.8 \mathrm{~cm} / \mathrm{kyr})$. The mean TOC MARs increase progressively from low values in the LST and moderate values in the TST-MFS to high values in the HST (Table S2).

\section{Discussion}

Prior to this study, most of the works dealing with dark levels within the Vocontian Basin (Weissert, 1990; Tribovillard and Gorin, 1991; Bréhéret, 1994; Föllmi, 1995; Sanfourche and Baudin, 2001; Friedrich et al., 2003; Herrle et al., 2003, 2010; Heimhofer et al., 2006; Stein et al., 2011; Westermann et al., 2013) were largely inspired by the usual two depositional models: the "productivity-driven model" and the "preservation-driven model" (Fig. 7; Schlanger and Jenkys, 1976; Demaison and Moore, 1980; Bralower and Thierstein, 1984; Arthur et al., 1990; Pedersen and Calvert, 1990; Erba, 1994; Erbacher et al., 1996, 1998, 2001; Premoli Silva et al., 1999; Leckie et al., 2002; Jenkyns, 2010; among others). Obviously, these traditional models partly explain the depositional conditions of the dark levels in the Marnes Bleues Fm., but recent works (Sageman et al., 2003; Harris, 2005; Bohacs et al., 2005; Burdige, 2005, 2006, 2007; Caillaud et al., 2020 and references therein) demonstrated that other factors must be considered such as: (1) the nature of $\mathrm{OM}$ (marine $v s$. terrestrial) (2) the dilution or concentration of $\mathrm{OM}$ in sediments (sedimentation rate, turbidites), (3) the geographical context of the Tethys Ocean (limited bottom-water renewal and possible inflow of trace-metal- and oxygen-depleted waters) and (4) the tectono-sedimentary context. The latter point is essentially concerned with relative sea-level variations that may be disconnected from eustatic variations because of all the twists and turns occurring during sedimentary basin evolution. Therefore, the depositional model may be updated in the light of the present results.

Before considering the various dark levels individually, some broad features may be derived from our results.

\subsection{Impact of burial}

From the Rock-Eval data, the OM maturity of the Marnes Bleues Fm. is low (immature stage to onset of oil window), except for the Baudinard section (upper end of oil window). The higher OM maturity of the Baudinard section may be explained by a thick burial and the proximity of the Alpine Thrust Front, as formerly deduced from the clay assemblages in the eastern part of the Vocontian Basin (Levert and Ferry, 1987, 1988; Deconinck, 1984, 1987; Levert and Ferry, 1988; Ghirardi et al., 2014; Caillaud et al., 2020). Based on 


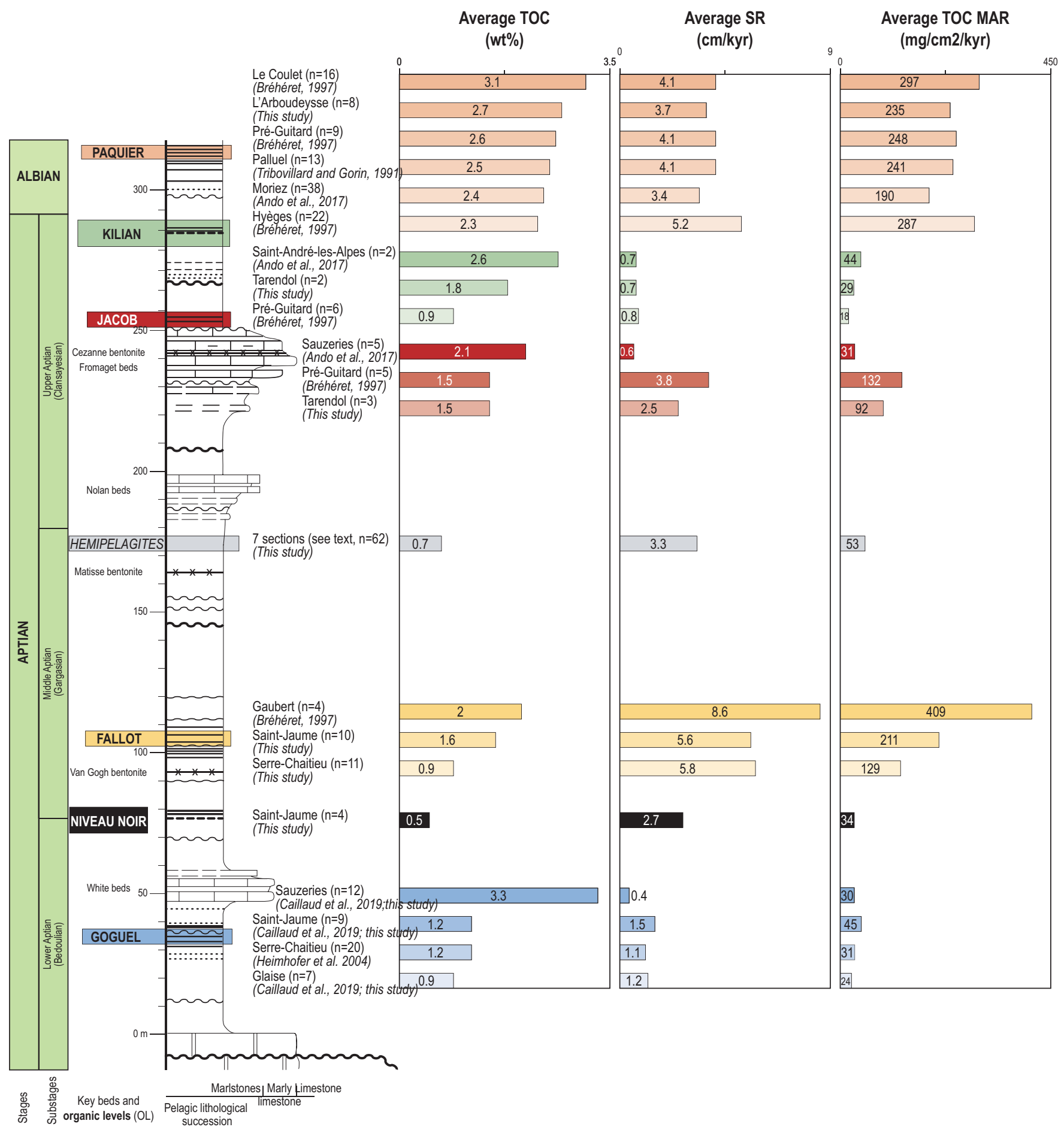

Fig. 6. Comparison of average TOC, SR, TOC MARs between the dark levels of the Aptian to Lower Albian interval, data from several works (Tribovillard and Gorin, 1991; Bréhéret, 1997; Heimhofer et al., 2004; Ando et al., 2017; Caillaud et al., 2020).

Fig. 6. Comparaison des MAR COT, SR, COT moyens entre les niveaux riches en MO de l'intervalle Aptien-Albien inférieur, données issues de plusieurs travaux (Tribovillard et Gorin, 1991; Bréhéret, 1997; Heimhofer et al., 2004 ; Ando et al., 2017; Caillaud et al., 2020). 

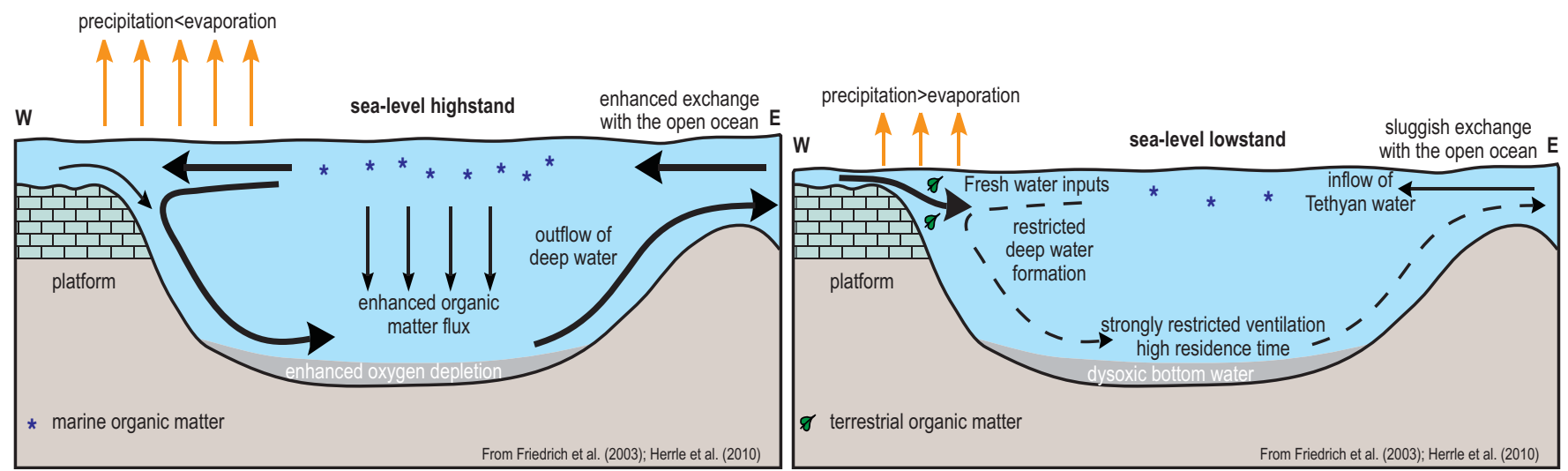

Fig. 7. Depositional model of dark levels of the Marnes Bleues Fm. (modified from Friedrich et al., 2003; Herrle et al., 2010).

Fig. 7. Modèle de dépôt des niveaux riches en MO des Marnes Bleues (modifié de Friedrich et al., 2003; Herrle et al., 2010).

clay-assemblage examination, Levert and Ferry (1987) estimated the burial depth in the western part of the Vocontian Basin to range between 500 and $1000 \mathrm{~m}$. Basing on unpublished data (Caillaud's PhD thesis) and on-going studies (Quijada et al., to be published), the low thermal maturity of the OM in the Marnes Bleues Fm. is also deduced from the biomarker isomerization ratios of the saturated fractions, as well as aromatic compounds such as phenanthrene and methylphenanthrene isomerization ratios (allowing vitrinite reflectance to be calculated at $\sim 0.63 \%$ ), which correspond to the beginning of the oil window..

\subsection{Conditions of oxygenation}

Largely, the redox-sensitive elements such as U, Mo, V, or even $\mathrm{Cr}$ show enrichment factors keeping to low values (below or close to the threshold limit) with some exceptions discussed below. After Algeo and Tribovillard (2009), it means that most of the samples point to oxic to occasionally suboxic conditions of deposition. The basin bottom did not undergo durably anoxic conditions and never reached euxinic conditions. In addition, a U-EF vs. Mo-EF diagram (Fig. 8; Algeo and Tribovillard, 2009) shows that some samples witnessed paleoenvironmental conditions prone to the particulate shuttle process. In a few words, in such situations, Mo may be conveyed to the sediments through capture onto iron and/or manganese oxy-hydroxides settling through a water column containing dissolved $\mathrm{O}_{2}$. Molybdenum was kept trapped within the sediments because reducing conditions developed at the sediment-water interface or at shallow distance below it (Fig. 8).

\subsection{Nature of OM, productivity and climate-induced nutrient supply}

Rock-Eval parameters show highly variable $\mathrm{HI}$ values in the Marnes Bleues Fm. (27 to $707 \mathrm{mgHC} / \mathrm{gTOC}$ ) corresponding to Type-II, Type-II-III and Type-III kerogens. These variable parameters suggest multiple origins for $\mathrm{OM}$. The molecular study (Quijada et al., to be published elsewhere) shows that all the levels studied here contain a mixture of marine $\mathrm{OM}$ and terrestrial $\mathrm{OM}$, present in various proportions. The Paquier, Kilian and Fallot levels are the most enriched in land-derived $\mathrm{OM}$.

In the Marnes Bleues Fm., the absence of authigenic enrichments of productivity-sensitive elements (Ni-, $\mathrm{Cu}-, \mathrm{Ba}-$ enrichment factors close to 1 and almost-always $<3$ ) indicates that surface-water productivity was low to normal during the deposition of the formation. Nevertheless, the proportion of smectite, within the clay-sized fraction of the sediment, and the IA, calculated from the bulk detrital fraction of the sediments, increased through the Aptian to Lower Albian interval. These variations could indicate enhanced nutrient inputs into the basin, through the increase of: (1) clay mineral abundance formed under moderately to strongly hydrolyzing on-land conditions (smectite and kaolinite; Chamley, 1989; Basilone et al., 2017); and, (2) IA values, related to chemical hydrolysis on land (Von Eynatten et al., 2003). Despite these observations, the increased IA and smectite proportion do not correlate with any enrichment of productivity-sensitive elements. These results suggest a climatic change evolving toward more hydrolyzing conditions from the Aptian to the Lower Albian.

\subsection{Sequence stratigraphy}

Organic-matter sedimentation may be placed in the sequence stratigraphy framework of the Marnes Bleues Fm. Thanks to the numerous samples studied here (LST, 20 samples; TST, 26 samples; MFS, 47 samples and HST, 39 samples), the sequence-stratigraphy interpretation can be somewhat refined. The sequence-stratigraphy pattern was designed from sedimentological considerations; here we can add some independent arguments. The interpretation of the distribution of clay minerals and IA is questionable because these factors display a long-term vertical trend throughout the Aptian to Lower Albian interval. The sediment composition fits well with the published sequence-stratigraphy framework: 1) the lowest average grain-size mode corresponds to the MFS $(24 \mu \mathrm{m})$, whereas the highest modes are in the LST and HST (38 and $35 \mu \mathrm{m}$, respectively); 2) the highest proportions of cohesive particles and sortable silts are located in the MFS (25 


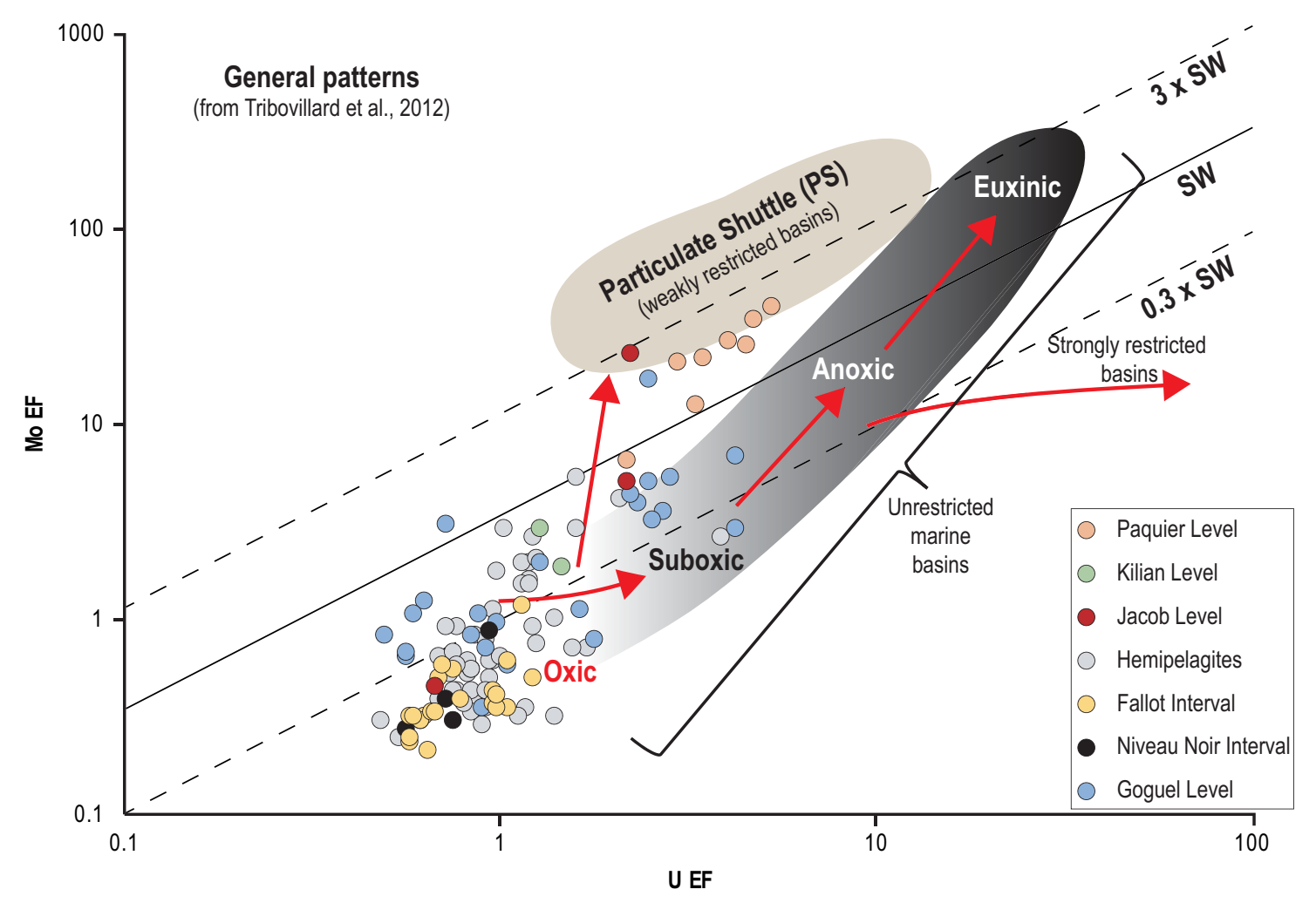

Fig. 8. Plot of U-EF vs. Mo-EF for the GL samples showing the oxygenation conditions in the Aptian to Lower Albian of the Marnes Bleues Fm. The SW lines corresponds to the Mo/U molar ratios similar to the seawater value ( $\mathrm{SW}$ 7.5-7.9) and the dashed lines correspond to the fractions thereof (3xSW, 0.3xSW). The pattern of $U$ and Mo EFs are compared to the model proposed in Algeo and Tribovillard (2009).

Fig. 8. Tracé de U-EF vs. Mo-EF pour les échantillons GL montrant les conditions d'oxygénation dans l'Aptien à l'Albien inférieur des Marnes Bleues Fm. Les lignes SW correspondent aux rapports molaires Mo/U similaires à la valeur de l'eau de mer (SW 7,5-7,9) et les lignes en pointillés correspondent à leurs multiple ou fraction $(3 x \mathrm{SW}, 0,3 x \mathrm{SW})$. Le modèle des FE U et Mo est comparé au modèle proposé dans Algeo et Tribovillard (2009).

and $43 \%$, respectively); and, 3 ) the highest average carbonate contents correspond to the LST $(41 \%)$ because the production of carbonates was restricted to the basin during the LST (Rubino, 1989; Friès and Parize, 2003). Several trends are also observed in the OM sedimentation. First, the highest TOC (1.9 $\mathrm{wt} \%$ on average) and HI $(256 \mathrm{mgHC} / \mathrm{gTOC}$ on average) are recorded during the MFS: most of the dark levels correspond to MFS. In the same way, the redox-sensitive molybdenum displays some enrichment in the MFS, which denotes low-oxygen deep waters during the MFS. The productivity-sensitive elements show a moderate enrichment of $\mathrm{Cu}$ in the LST, probably related to the high biogeniccarbonate contents. The SRs were also consistent with the system tract, with the highest average SRs in the LST and HST ( 3 and $4.8 \mathrm{~cm} / \mathrm{kyr}$ ) and the lower average SR in the MFS $(1.8 \mathrm{~cm} / \mathrm{kyr})$. Nevertheless, the highest TOC MARs do not occur in the MFS $\left(76 \mathrm{mg} / \mathrm{cm}^{2} / \mathrm{kyr}\right)$ but in the HST $(114 \mathrm{mg}$ / $\mathrm{cm}^{2} / \mathrm{kyr}$ ). Thus, the tectono-sedimentary-controlled variations of the sea level are accurately recorded by the organic content of the dark levels, as reported by Basilone (2020, 2021a) for similar contexts of deposition. Therefore, it is assumed that the MFS display the best conditions for OM preservation (low oxygenation and SRs) in the Marnes Bleues Fm. Another evidence is that all dark levels were deposited in a high relative sea-level context (TST, MFS and HST), implying that a low relative sea level (LST) was not favorable to OM preservation.

\subsection{The dark levels considered individually}

The dark level can be assessed each in turn, after an initial look at the background sedimentation. The main factors identified for each level are summarized in Figure 9.

Thehemipelagites correspond to the background sedimentation of the Marnes Bleues Fm. Their OM content is low (mean $\mathrm{TOC}=0.7 \mathrm{wt} \%$ ) and they were deposited under oxic conditions with low to normal productivity. Based on molecular biomarker analysis, the hemipelagites present mostly algal-bacterial OM, and Type-III to Type-II/III kerogens, implying a notable contribution of continental $\mathrm{OM}$ and/or degraded marine-OM. The hemipelagites show slightly higher grain-size modes than most of the dark levels and they correspond to marlstones while the dark levels correspond to siltstones. The average SR and TOC MARs of hemipelagites are used as a baseline to be compared with other SRs and TOC MARs in the Marnes Bleues Fm.

TheGoguel Level shows contrasting results depending on the sections examined. These results were intensively discussed in Caillaud et al. (2020), therefore only a summary 

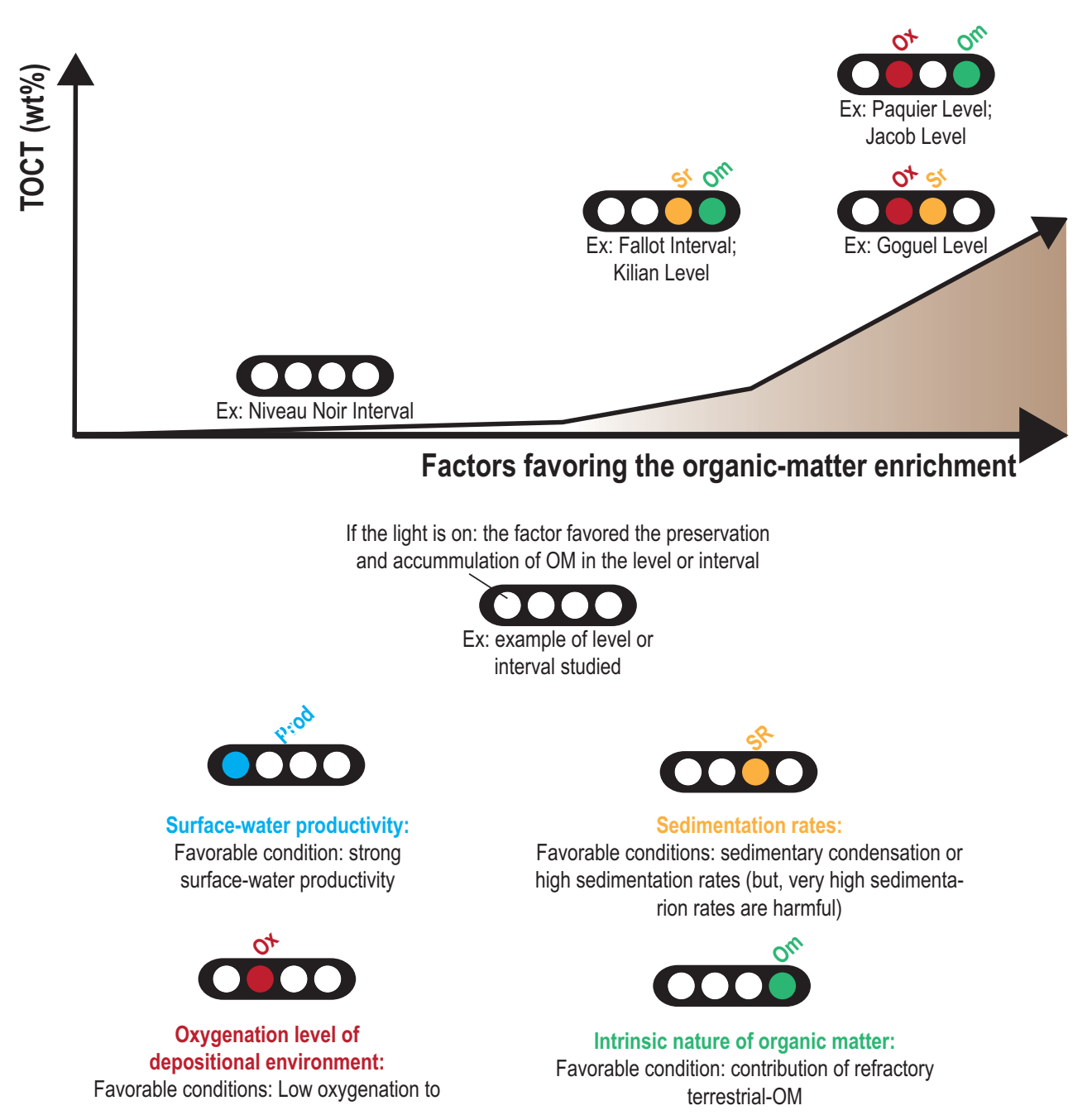

Fig. 9. Synthesis of factors and processes that controlled OM sedimentation in the Aptian to Lower Albian interval of the Marnes Bleues Fm. Fig. 9. Synthèse des facteurs et processus contrôlant la sédimentation de la MO dans l'intervalle Aptien à Albien inférieur des Marnes Bleues.

of the main interpretations is presented here. First, although the average TOC is $1.9 \mathrm{wt} \%$, the section of Sauzeries exhibits high average TOC (3.3 wt $\%)$ and $\mathrm{HI}(387 \mathrm{mgHC} / \mathrm{gTOC})$ but a low average TOC MAR $\left(30 \mathrm{mg} / \mathrm{cm}^{2} / \mathrm{kyr}\right)$. Second, the surfacewater productivity was low to normal, but the oxygenation conditions were heterogeneous. As demonstrated by the redoxsensitive elements and molecular biomarkers, in the proximal environments the conditions were oxic, while in the distal settings the conditions were lowly oxygenated. In addition, the biomarker data suggest the water column was intermittently stratified with hypoxia/anoxia occasionally developing into the photic zone. In the same way, although the OM was mainly of marine origin, a significant terrestrial contribution was evidenced in the proximal environments through biomarker examination. Third, the Goguel Level was deposited during a period of sedimentary condensation indicated by the low average SRs $(0.4 \mathrm{~cm} / \mathrm{kyr}$ to $1.5 \mathrm{~cm} / \mathrm{kyr})$ compared to the hemipelagites. In more detail, the very low average SR at Sauzeries $(0.4 \mathrm{~cm} / \mathrm{kyr})$ corresponds to the section devoid of turbidites, on the contrary of the Notre-Dame, Saint-Jaume, Glaise and Serre-Chaitieu sections, where thin turbidites are interbedded. In addition to the sedimentary condensation, the low average grain-size mode and the high proportions of cohesive particles and sortable silts (27 and $44 \%$ on average, respectively), compared to the hemipelagites, are consistent with the 3rd order MFS position in a sequence stratigraphy framework (Rubino, 1989; pers. com. 2017; Bréhéret, 1997; Ferry, 2017).

To summarize, the depositional model of the Goguel Level in the Vocontian Basin encompasses three distinct environments (Caillaud et al., 2020): (1) a proximal area (Saint-Jaume and Notre-Dame sections) where mixed-origin $\mathrm{OM}$ was diluted by turbidites and remineralized (oxic conditions); (2) a distal area (Glaise section) where marine OM was diluted and remineralized (both process induced by turbidites) under lowoxygen conditions; and, (3) a distal area (Sauzeries section) without turbidites, where marine $\mathrm{OM}$ was condensed and preserved under low-oxygen conditions. Therefore, in the case of the Goguel Level, although the mixed nature of OM contributed to a slightly more efficient preservation in the proximal areas, the two factors that significantly contributed to $\mathrm{OM}$ enrichment are sedimentary "condensation" and low 
"oxygenation level" (stratified basin with oxygen-poor bottom-waters).

TheNiveau Noir Interval was categorized as an organicrich level in the literature, but it is not enriched in OM (aver. TOC of $0.5 \mathrm{wt} \%$; aver. HI of $67 \mathrm{mgHC} / \mathrm{gTOC}$ ). Organic matter is mostly composed of marine OM without significant contribution from terrestrially-derived biomarkers, deposited under oxic conditions with modest SRs $(2.7 \mathrm{~cm} / \mathrm{kyr}$ on average). Although Herrle et al. (2010) proposed a period of strong surface-water productivity coupled to evaporation), our new dataset indicates that surface-water productivity was normal to moderate, because only $\mathrm{Cu}$ exhibits a detectable (yet rather weak) enrichment factor. The Niveau Noir Interval is thus definitely not an organic-rich level, because "no factor" significantly contributed to $\mathrm{OM}$ enrichment. The results of grain-size analysis display an average mode of $20 \mu \mathrm{m}$ and sediments composed of relatively abundant cohesive particles and sortable silts (26 and $42 \%$ on average, respectively) compared to the hemipelagites. Therefore, this fine-grained sediment composition is consistent with the sequencestratigraphy framework, where the Niveau Noir Interval is interpreted as a 3rd order MFS (Rubino, 1989; Friès and Parize, 2003).

TheFallot Interval shows low to moderate average TOC (1.2 wt $\%, 0.6$ and $1.6 \mathrm{wt} \%$ in the studied sections) with relatively low average HI (106 $\mathrm{mgHC} / \mathrm{gTOC})$. Rock-Eval data indicate the presence of Type-III kerogens. Molecular biomarkers indicate an important contribution of terrestrially-derived OM. The inorganic geochemistry and biomarkers clearly indicate that the Fallot Interval was deposited under oxic conditions with low to normal surface-water productivity. However, the average SR $(5.7 \mathrm{~cm} / \mathrm{kyr})$ and TOC MARs $\left(168 \mathrm{mg} / \mathrm{cm}^{2} / \mathrm{kyr}\right)$ were very high compared to hemipelagites. In the same way, the grain-size mode indicates relatively high values ( $42 \mu \mathrm{m}$ on average), as is the case for the average sand proportion in the sediments (14\%). The high SRs and the coarser grain size of the Fallot Interval are consistent with the HST position proposed by Rubino (1989) and Friès and Parize (2003). The depositional model proposed for the Fallot Interval (alternation of the "preservation-driven model" with the "productivity-driven model", Friedrich et al., 2003) is not consistent with our new findings. Consequently, we propose the following factors influenced OM enrichment: (1) dilution (because of the very high SRs); and, (2) oxygenation conditions (i.e., oxic in the case of the Fallot Interval). According to Tyson (2001, 2005), in oxic environments, increased SRs can be correlated with increased organic-carbon burial. The oxygen level is considered only a minor process in this case because, under low-oxygen conditions, high SRs are harmful to the organic contents in that they act as a diluting agent (Tyson, 2001, 2005). Nevertheless, even if the SRs of the Fallot Interval were high, they did not fall in the range proposed by Tyson (2005), i.e., more than $20 \mathrm{~cm} / \mathrm{kyr}$. Therefore, OM preservation was probably enhanced by one additional factor: the "nature of OM". Organic matter was partly composed of land-derived, refractory organic compounds. This model is coherent with the data of Bréhéret (1997) regarding the Gaubert section: the highest average SRs match with the highest TOCs. To summarize, the moderate OM enrichment for the Fallot Interval is the consequence of the fast burial of terrestrial OM under oxic conditions.
The Jacob Level shows moderate organic contents (mean TOC of $1.5 \mathrm{wt} \%$ ) of Type-II to-III kerogen. This level contains mixed OM with an important contribution of land-derived products, inferred from molecular data. In addition, palynofacies data indicate high contributions of terrestrial OM (Heimhofer et al., 2006). In the studied section (Tarendol), the average SR $(2.5 \mathrm{~cm} / \mathrm{kyr})$ and the surface-water productivity were normal compared to the background sedimentation (hemipelagites). In the Pré-Guittard section (data from Bréhéret, 1997), approximately the same values of average SR, TOC MAR, and TOC were reported. However, inorganic geochemistry indicates that bottom conditions were poorly oxygenated (at least periodically) during the Jacob Level. The biomarkers corroborate this assumption. The mode of the grain-size distribution $(21 \mu \mathrm{m}$, that is, lower than for hemipelagites) and the proportions of cohesive particles and sortable silts (23 and 39\%, higher than for hemipelagites) are coherent with the position within the sequence-stratigraphy framework (MFS). The depositional model proposed by Heimhofer et al. (2006), that is, the "preservation-driven model", is consistent with the evidences of low-oxygenated conditions demonstrated here. Nevertheless, we propose that the refractory nature of the terrestrial OM deposited favored $\mathrm{OM}$ preservation. To conclude, the enrichment of $\mathrm{OM}$ in the Jacob Level resulted from two major parameters: the "oxygenation level" (low-oxygenated bottom-waters) and the "nature of OM" (refractory continental OM). In this dark level, the addition of a minor factor, the low dilution (favoring sedimentary condensation of $\mathrm{OM}$ ), led to the highest organic contents (mean TOC of $2.1 \mathrm{wt} \%$ ) in the Sauzeries section. This point, plus the nature of the OM, illustrates the role played by the relative sea-level variations at this regional scale.

TheKilian Level contains Type-III kerogens (124 mgHC/ gTOC) and the organic contents show a moderate enrichment of $1.8 \mathrm{wt} \%$ on average. In the sequence-stratigraphy framework, this dark level is interpreted as a HST, which is in adequacy with the slightly lower mode values $(26 \mu \mathrm{m}$ on average) and the higher proportions of cohesive particles and sortable silts ( 23 and $43 \%$ on average, respectively) compared to the background sedimentation. The OM from this interval is composed of marine products, with a significant presence of terrestrial biomarkers deriving from conifers Quijada et al, ongoing study). Our new results suggest the Kilian Level was deposited under oxic conditions. However, the work of Okano et al. (2008) found tri- and penta-methylicosanes (TMI and PMI) in the Kilian Level at the Sauzeries section (same samples as those studied by Ando et al., 2017). Such TMI and PMI indicate the occurrence of methanogenic archaea and, therefore, low-oxygen conditions at the sediment/water interface. Surface-water productivity was low to normal. In the Tarendol section, the low average SR $(0.7 \mathrm{~cm} / \mathrm{kyr})$ is interpreted as a sedimentary condensation, and, according to Bréhéret (1997) and Ando et al. (2017), the Sauzeries and PréGuittard sections yield average SRs of the same range of values. Hitherto the depositional model assigned to the Kilian Level was the "preservation-driven model" (Herrle et al., 2003), but our results are not totally concordant with this model. We propose that the main two parameters that contributed to OM preservation were the "dilution level" (here: condensation of $\mathrm{OM}$ ) coupled to the "nature of OM" (here: contribution of refractory terrestrial OM). The 
depositional model proposed by Herrle et al. (2003) could be consistent locally for the Sauzeries section, where the highest average TOC values are recorded $(2.6 \mathrm{wt} \%$, using data of Ando et al., 2017). In addition to sedimentary condensation, the likely low-oxygen conditions favored the preservation of terrestrial and marine OM in the Kilian Level.

ThePaquier Level shows uniformly "high" average TOC (2.3 to $3.1 \mathrm{wt} \%$ ) and moderate SRs (3.4 to $5.2 \mathrm{~cm} / \mathrm{kyr})$. The Van-Krevelen-type diagram indicates Type II-III to Type-II kerogens for the samples studied in the L'Arboudeysse section. Biomarkers suggest marine $\mathrm{OM}$ with the highest relative contribution of terrestrial OM including leaf waxes. The contribution of terrestrial OM was also demonstrated with palynofacies data (Tribovillard and Gorin, 1991). Biomarker results clearly show that the Paquier Level was deposited under intermittent anoxic conditions. In addition, our results meet those of Benamara et al. (2020) when they point to conditions favoring the particulate shuttle-induced transfer of Mo to the sediments, which indicates depositional setting conditions with an oxygenated water column and the developments of reducing conditions at shallow depth below the sedimentwater interface. Based on the interpretation of the productivitysensitive elements, surface-water productivity was low to normal. At first, this interpretation seems to be inconsistent with the high average TOC MARs calculated (190 to $297 \mathrm{mg} /$ $\mathrm{cm}^{2} / \mathrm{kyr}$ ), however, we assume that moderate SRs coupled to a significant proportion of refractory continental OM deposited under low-oxygen conditions allowed for this range of values. The sediment composition of the Paquier Level is partially consistent with a 3rd order MFS in the Vocontian Basin. Indeed, even if the average mode of the grain-size is lower in the Paquier Level $(26 \mu \mathrm{m})$ than in the hemipelagites, sediment composition is relatively similar to that of hemipelagites. Our new insights partially support the previous depositional model proposed by Herrle et al. (2003) with a significant productivity and a strong continental runoff (Tribovillard and Gorin, 1991; Benamara et al., 2020), as no increase of surface-water productivity is observed. The deposition of OM in the Paquier Level was governed by two main parameters: the "oxygenation level" (recurrent anoxic conditions) and the "nature of OM" (here mixed origin of $\mathrm{OM}$ ). For the latter factor, it is conceivable that the labile marine $\mathrm{OM}$ was preserved during the anoxic period in addition to land-derived OM, while the refractory terrestrial $\mathrm{OM}$ alone was preserved during the suboxic-oxic periods. In addition, a high accumulation of $\mathrm{OM}$ (TOC MARs) was the outcome of moderate SRs associated with high continental runoff. The wholesale constancy of SRs (based on 6 sections) is consistent with previous works of Bréhéret (1997), demonstrating that the Paquier Level has a large geographic extension throughout the Vocontian Basin.

\section{Regional and global controls}

The weathering proxies (smectite and IA) show a progressive increase during the entire deposition of the Marnes Bleues Fm. Either for the IA or smectite, this trend is interpreted as an intensification of chemical weathering affecting the clastic-sediment sources on land. This long-term evolution was probably induced by climate warming, in particular during the latest Aptian. It is consistent with the nannofossil-based temperatures variation curve reconstructed by Godet et al. (2008), Bottini et al. (2015) and Bottini and Erba (2018) for the western Tethys, and also with the TEXH86-SST data of O'Brien et al. (2017). In addition, it is proposed here that one process could have been superimposed onto the clay mineral record and terrigenous fraction, namely, the Vocontian Basin long-term evolution. According to previous works (Bréhéret, 1997; Ferry, 1999, 2017; Friès and Parize, 2003), the Vocontian Basin was progressively constricted during the Aptian and Albian by the uplift of the Vivarais and Dauphiné platforms and the uplift of the Durancian Isthmus. Consequently, the source-to-sink distance decreased during the Aptian to Lower Albian. Thus, we propose that: (1) the Goguel Level recorded a distal signature of mixed terrigenous-materials, because of the larger distance from sedimentary sources, also reinforced by a global high sea level during the OAE1a (Haq et al., 1987; Hardenbol et al., 1998; Haq, 2014); (2) the progressive closure of the Vocontian Basin allowed the climate changes on the closer-and-closer sediment sources to be recorded. To summarize, the nature of $\mathrm{OM}$, and more particularly the relative contribution of continental OM in the dark levels, was controlled by: (1) the climatic conditions that could have stimulated the production of terrestrial OM (warm and humid conditions); and (2) the tectonic settings, which must have favored the export of terrestrial OM, depending on the distance to the coasts, evolving through time. The omnipresent control by the sea-level variations driven by the tectonic-sedimentation interaction must not be forgotten, as reminded at various places above.

In the same way, marine primary productivity could have been controlled by the conjunction of climatic conditions and local basin physiography. In the Marnes Bleues Fm., according to our results, surface-water productivity was low to normal. Incidentally, Gambacorta et al. (2020) have the same conclusion for an equivalent of OAE1d, namely, the Pialli Level of the Umbria-Marche Basin (central Italy). This basin also accumulated dark grey to black shales under oxic to suboxic conditions. Therefore, like for the nature of OM, surface-water productivity may have resulted from: (1) specific climatic conditions favoring nutrient export; and, (2) specific basin physiography favoring nutrient concentration.

Unlike the dilution and nature of OM, the oxygenation level of the Vocontian Basin may have been controlled by global processes in addition to regional factors. The oxygenation factor seemed closely linked to the second order eustatism and to the submarine-volcanic activity: (1) the Goguel Level resulted from a global high sea level during the emplacement of the Ontong-Java Plateau (OAE1a); (2) the Jacob Level was formed during the maximum of the global regression in the Tethys Ocean coupled to the Kerguelen Plateau; (3) the Paquier Level was deposited after a return to a global high sea-level context, contemporaneous of the Nauru and Kerguelen Plateaus, as illustrated by the works of Bottini et al. (2015) and Bottini and Erba (2018). Thus, the periods of deposition of the Goguel, Jacob, and Paquier levels were marked by brief hyperthermal events, associated with the large igneous provinces (LIP). These global events may have triggered low-oxygen conditions during Mid-Cretaceous interval (Bodin et al., 2015; Vickers et al., 2016). 
The global high sea level (Paquier and Goguel levels) could have favored the development of oxygen-depleted deep areas of the semi-enclosed Vocontian Basin. In the case of the global sea-level fall in the Tethys Ocean (Jacob Level), the Vocontian Basin could have been partly isolated, involving a limited renewal of deep waters (as already mentioned by Bréhéret, 1994). Concurrent regional or global factors must have occurred, each of them yielding contrasting periodicities or durations, which entangled the sedimentary record. Thus global, LIP-related (thermal) events may have conditioned the oxygen-level of oceanic water masses and sea-level variations may have conditioned the renewal of the Vocontian water masses, depending on the type of exchanges between the Tethys Ocean and the relatively isolated Vocontian Basin.

From numerous works related to Tethyan basins (e.g., Coccioni et al., 1990, 2006; Baudin et al., 1998; Leckie et al., 2002; Föllmi, 2012; Sabatino et al., 2015, 2018) and the North Atlantic (Trabucho Alexandre, 2011), the comparison of organic-rich levels in the Marnes Bleues Fm. (Goguel, Jacob, Kilian and Paquier levels; TOC of $1-3 w t \%$ on average) and their time equivalents (Livello Selli, Level 113, Kilian Level and Livello Urbino; TOC $>3 \mathrm{wt} \%$ on average) reveals that: (1) the nature of OM was totally different from that of the Marne Bleues background, being exclusively marine, confirming that the nature of OM was partly controlled by local environmental factors and paleogeography; (2) SRs were logically lower in the deep oceans compared to the Vocontian Basin (0.22 to $0.47 \mathrm{~cm} / \mathrm{kyr}$ for the Level 113 to Livello Urbino, Sabatino et al., 2018; and 0.12 to $0.27 \mathrm{~cm} / \mathrm{kyr}$ for the Selli Level, Westermann et al., 2013), supporting that dilution depended on the location within the Tethys Ocean (platform vs. slope $v s$. deep basin); (3) the depositional conditions were dysoxic to anoxic in all black-shales time-equivalents, induced by the emplacement of large igneous provinces, (4) surface-water productivity was strong in all black-shale being timeequivalents of the dark levels of the Vocontian Basin (even if it was variable in the Kilian Level between the North Atlantic and the Tethys Ocean, (Trabucho Alexandre et al., 2011; Sabatino et al., 2015), highlighting a global control like for the oxygenation conditions (probably the volcanic activity too, Larson and Erba, 1999; Leckie et al., 2002; Trabucho Alexandre et al., 2010, 2011). We can thus hypothesize that the black shales of the Tethys Ocean were richer in OM because they were more condensed and the productivity was more intense than in the Vocontian Basin.

\section{Conclusion}

Because the Vocontian Basin was a medium-size basin accumulating thick and apparently homogenous successions of marly/shaly sediments, the OM-rich levels studied here could have been expected to share the same controls. In addition, the semi-enclosed disposition of the basin is supposed to have favored the development of oxygen-limited conditions. Surprisingly, our study demonstrates that each dark level resulted from a different scenario and that the organic content was low (TOC $<3 \%$ ). The various parameters influencing $\mathrm{OM}$ storage differ from one level to one another: proportions of marine vs. terrestrial $\mathrm{OM}$, sedimentation and accumulation rates, redox conditions, productivity, sea level, etc. This intrabasinal fluctuation of the factors impacting OM accumulation is to be considered in a larger-scale framework, where regional to global factors also evolve: tectonics modifying the basin geometry, climate, (eustatic) sea-level variations, LIP emplacements, etc. Nevertheless, all dark levels of the Vocontian Basin were deposited under low-to-normal conditions of productivity and all levels (but the Paquier Level) underwent oxic to suboxic conditions. The factors favoring the accumulation of $\mathrm{OM}$ other than productivity and anoxia have been brought into play, either in turn or in synergy, in the various situations illustrated by the organic levels of the Vocontian Basin. Nevertheless, it is observed that in the absence of productivity and/or anoxia favorable to preservation, these other factors only account for (very) low enrichments in OM. They would therefore only be capable to modulate the response of the organic record but not to cause marked enrichments. Therefore, a semi-enclosed environment such as that of the Vocontian Basin did not favor the development of oxygen-restricted conditions with a modest productivity, although additional factors enhancing $\mathrm{OM}$ accumulation were operating. Thus our results strongly suggest that hemipelagic environments collecting thick successions of marly/shaly sediments cannot accumulate $\mathrm{OM}$ in significant proportions if a high productivity is absent from surface waters.

These results discussed here are not typically specific to the Cretaceous Vocontian basin that displays quite common features, i.e., a medium-sized, semi-enclosed basin where hemipelagic sediments accumulated below a water depth of a few hundreds of meters. Consequently, we argue that our conclusion could be applied to similar basins, independently of their time of formation and location.

\section{Supplementary Material}

Table S1. Details for log-sections sampled (coordinates and sources). Localization in.

Table S2. Synthesis of OM, SRs and TOC MARs data. For details, see Table S7.

Table S3. Accumulation rates calculated for the sections studied from literatures and positions of samples in the sequence-stratigraphy framework.

Table S4. Accumulation rates calculated from literatures.

Table S5. Grain-size data (in $\%$ of the terrigenous fraction and in $\%$ of the bulk sediment).

Table S6. Clay mineral composition (in \% of the clay-mineral fraction and in $\%$ of the bulk sediment).

Table S7. Rock-Eval parameters and the carbonate contents calculated from the MINC (\%).

Table S8. Geochemical data (major and trace elements) of the studied samples. $<$ LD means below limit of detection.

Table S9. Geochemical data (Al-normalized concentrations and enrichment factors) of the studied samples. $<$ LD means below limit of detection. EF stands for enrichment factor (see text).

The Supplementary Material is available at http://www.bsgf.fr/ 10.1051/bsgf/2022001/olm.

Acknowledgements. We thank TOTAL S.A. for funding this research, Monique Gentric for administrative management, Marion Delattre and Romain Abraham for technical support. Thanks to Jean-François Deconinck, Alexis Godet and 
Thomas Algeo for kind and helpful discussions that improved significantly this manuscript. Clara J. Brennan is thanked for editing the text. We thank the two referees for their reviews as well as Laurent Jolivet and Cécile Robin, editors of the journal for their commitments.

\section{References}

Algeo TJ, Tribovillard N. 2009. Environmental analysis of paleoceanographic systems based on molybdenum-uranium covariation. Chemical Geology 268: 211-225.

Ando T, Sawada K, Okano K, Takashima R, Nishi H. 2017. Marine primary producer community during the mid-Cretaceous oceanic events (OAEs) 1a, 1b and 1d in the Vocontian Basin (SE France) evaluated from triaromatic steroids in sediments. Organic Geochemistry 106: 13-24.

Arnaud-Vanneau A, Arnaud H. 1991. Sédimentation et variations relatives du niveau de la mer sur les plates-formes carbonatées du Berriasien-Valanginien et du Barrémien dans les massifs subalpins septentrionaux et le Jura (SE de la France). Bull. Soc. géol. Fr. 162: 535-545.

Arthur MA, Jenkyns HC, Brumsack HJ, Schlanger SO. 1990. Stratigraphy, geochemistry, and paleoceanography of organic carbon-rich Cretaceous sequences. In: Ginsburg RN, Beaudoin B, eds. Cretaceous Resources, Events and Rhythms: Background and Plans for Research. NATO ASI Series C 304: 75-119.

Attewell PB, Farmer IW. 1976. Principles of Engineering Geology. London: Chapman and Hall.

Babos HB, Stuart S, Pluskowski A, Brown A, Rohrssen MK, Chappaz A. 2019. Evidence for the onset of mining activities during the 13th century in Poland using lead isotopes from lake sediment cores. Science of the Total Environment 683: 589-599.

Basilone L. 2020. Mesozoic tectono-sedimentary evolution of the Trapanese Southern Tethyan margin (NW Sicily) integrating facies and stratigraphic analysis with subsidence history. Italian Journal of Geosciences 139: 54-75.

Basilone L. 2021a. Synsedimentary tectonics vs. paleoclimatic changes across the Aptian-Albian boundary along the Southern Tethyan margin: The panormide carbonate platform case history (NW Sicily). Marine and Petroleum Geology 124: 104801.

Basilone L. 2021b. Valanginian cold/warm climatic oscillation and synsedimentary tectonic interaction for drowning the carbonate platform of Southern Tethys (Sicily). Sedimentary Geology 423: 105991.

Basilone L, Perri F, Sulli A, Critelli S. 2017. Paleoclimate and extensional tectonics of short-lived lacustrine environments. Lower Cretaceous of the Panormide Southern Tethyan carbonate platform (NW Sicily). Marine and Petroleum Geology 88: 428-439.

Baudin F, Fiet N, Coccioni R, Galeotti S. 1998. Organic matter characterisation of the Selli Level (Umbria-Marche Basin, Central Italy). Cretaceous Research 19: 701-714.

Beaudoin B, Friès G, Joseph P, Bouchet R, Cabrol C. 1986. Tectonique synsédimentaire crétacée à l'Ouest de la Durance (SE France). C. R. Acad. Sci. Paris 303: 713-718.

Behar F, Beaumont V, De B, Penteado HL. 2001. Technologie RockEval 6: performances et développements. Oil Gas Sci. Technol. Rev. Inst. Fr. Pétrole 56: 111-134.

Benamara A, Charbonnier G, Adatte T, Spangenberg JE, Föllmia KB. 2020. Precession-driven monsoonal activity controlled the development of the early Albian Paquier oceanic anoxic event (OAE1b): Evidence from the Vocontian Basin, SE France. Palaeogeography, Palaeoclimatology, Palaeoecology 537: 109406.
Bodin S, Meissner P, Janssen NMM, Steuber T, Mutterlose J. 2015. Large igneous provinces and organic carbon burial: Controls on global temperature and continental weathering during the Early Cretaceous. Global and Planetary Change 133: 238-253.

Bohacs KM, Grabowski GJ, Caroll AR, Mankiewicz PJ, MiskellGerhardt KJ, Schwalbach JR, et al. 2005. In: Harris NB, ed. The Deposition of Organic-Carbon-Rich Sediments: Models, Mechanisms and Consequences. Special Publications of SEPM, pp. 31-101.

Bottini C, Erba E. 2018. Mid-Cretaceous paleoenvironmental changes in the western Tethys. Climate of the Past Discussions 1-23.

Bottini C, Erba E, Tiraboschi D, Jenkyns HC, Schouten S, Sinninghe Damsté JS. 2015. Climate variability and ocean fertility during the Aptian Stage. Climate of the Past 11(3): 383-402.

Bout-Roumazeilles V, Eisa C, Laurent L, Pierre D. 1999. Clay mineral evidence of nepheloid layer contributions to the heinrich layers in the Northwest Atlantic. Palaeogeography, Palaeoclimatology, Palaeoecology 146(1-4): 211-28.

Bralower T, Thierstein H. 1984. Low productivity and slow deepwater circulation in mid-Cretaceous oceans. Geology 12(10): 614 618.

Bralower TJ, Sliter WV, Arthur MA, Leckie RM, Allard DJ, Schlanger SO. 1993. Dysoxic/anoxic episodes in the Aptian-Albian (Early Cretaceous). In: Pringle MS, Sager WW, Sliter WV, Stein S, eds. The Mesozoic Pacific: Geology, Tectonics and Volcanism. Geophysical Monograph Series 77. Washington, D.C.: AGU, pp. 5-37.

Bralower TJ, Cobabe E, Clement B, Sliter WV, Osburn CL, Longoria J. 1999. The record of global change in mid-Cretaceous (Barremian-Albian) sections from Sierra Madre, northeastern Mexico. Journal of Foraminiferal Research 29: 418-437

Bréhéret JG. 1994. The Mid-cretaceous organic-rich sediments from the Vocontian Zone of the French Southeast Basin. In: Mascle A, ed. Hydrocarbon and Petroleum Geology of France, Special Publication EAPG 4: 295-320.

Bréhéret JG. 1997. L'Aptien et l'Albien de la fosse vocontienne (des bordures au basin). Évolution de la sédimentation et enseignements sur les évènements anoxiques. Ph.D. Thesis. University of Tours, France. Publication Société Géologique du Nord 25, 614 p.

Burdige DJ. 2005. Burial of terrestrial organic matter in marine sediments: A re-assessment. Global Biogeochemical Cycles 19.

Burdige DJ. 2006. Geochemistry of Marine Sediments. Princeton: Princeton University Press.

Burdige DJ. 2007. Preservation of organic matter in marine sediments: Controls, mechanisms, and an imbalance in sediment organic carbon budgets? Chemical Reviews 107(2): 467-485.

Caillaud A, Quijada M, Huet B, Reynaud J-Y, Riboulleau A, BoutRoumazeilles V, et al. 2020. Turbidite-induced re-oxygenation episodes of the sediment-water interface in a diverticulum of the Tethys Ocean during the Oceanic Anoxic Event 1a: The French Vocontian Basin. The Depositional Record 6: 352-382.

Chamley H. 1989. Clay sedimentology. Berlin: Springer Verlag.

Coccioni R, Franchi R, Nesci O, Perilli N, Wezel FC, Battistini F. 1990. Stratigrafia, micropaleontologia e mineralogia delle Marne a Fucoidi delle sezioni di Poggio le Guaine e del Fiume Bosso (Appennino umbro-marchigiano). In: Atti $2^{\circ}$ Convegno Internazionale "Fossili, Evoluzione, Ambiente", Pergola, 25-30 ottobre 1987, Tecnostampa, pp. 163-201.

Coccioni R, Luciani V, Marsili A. 2006. Cretaceous oceanic anoxic events and radially elongated chambered planktonic foraminifera: Paleoecological and paleoceanographic implications. Palaeogeography, Palaeoclimatology, Palaeoecology 235: 66-92.

Corentin P, Deconinck J-F, Pellenard P, Amédro F, Bruneau L, Chenot E, et al. 2020. Environmental and climatic controls of the clay 
mineralogy of Albian deposits in the Paris and Vocontian basins (France). Cretaceous Research 108: 104342

Cotillon P, Banvillet M, Gaillard C, Groshény D, Olivero D. 2000. Les surfaces à Rhizocorallium de l'Aptien inférieur sur la bordure méridionale du bassin vocontien (France Sud-Est), marqueurs de dynamiques locales; leur relation avec un événement anoxique global. Bull. Soc. géol. Fr. 171: 229-238.

Dauphin L. 2002. Litho-, bio- et chronostratigraphie comparées dans le bassin vocontien, à l'Aptien. Ph.D. Thesis, University of Lille I, France, $516 \mathrm{p}$.

Deconinck J-F. 1984. Sédimentation et diagénèse des minéraux argileux du Jurassique supérieur-Crétacé dans le Jura meridional et le domaine subalpine (France Sud-Est); comparaison avec le domaine Atlantique Nord. Ph.D. Thesis, University of Lille, $150 \mathrm{p}$.

Deconinck J-F. 1987. Identification de l'origine détritique ou diagénétique des assemblages argileux: le cas des alternances marne-calcaire du Crétacé inférieur subalpin. Bull. Soc. géol. France III(1): 139-145.

Demaison G, Moore GT. 1980. Anoxic environment and oil source bed genesis. AAPG Bulletin 64: 1179-1209.

Erba E. 1994. Nannofossils and superplumes: The early Aptian "nannoconid crisis". Paleoceanography 9(3): 483-501.

Erba E, Coccioni R, Premoli Silva I. 1989. The "Scisti a Fucoidi" in the Umbria-Marche area: The Apecchiese road sections. Mem Descr Carta Geol Ital 39: 146-164.

Erba E, Duncan RA, Bottini C, Tiraboschi D, Weissert H, Jenkyns $\mathrm{HC}$, et al. 2015. Environmental consequences of Ontong Java Plateau and Kerguelen Plateau volcanism. Geological Society of America Special Papers. Geological Society of America, SPE511-15.

Erbacher J, Thurow J, Littke R. 1996. Evolution patterns of radiolaria and organic matter variations: A new approach to identify sea level changes in mid-Cretaceous pelagic environments. Geology 24: 499-502.

Erbacher J, Gerth W, Schmiedl G, Hemleben C. 1998. Benthic foraminiferal assemblages of late Aptian early Albian black shale intervals in the Vocontian Basin, SE France. Cretaceous Research 19: 805-826.

Erbacher J, Huber BT, Norris RD, Markey M. 2001. Increased thermohaline stratification as a possible cause for an ocean anoxic event in the Cretaceous period. Nature 409: 325.

Espitalié J. 1993. Rock-Eval pyrolysis. In: Bordenave ML, ed. Applied Petroleum Geochemistry. Paris : Technip, pp. 237-261.

Espitalié J, Deroo G, Marquis F. 1985. La pyrolyse Rock-Eval et ses applications. Rev. l'Inst. Fr. Pétrol. 40: 563-579.

Ferry S. 1999. Apports des forages ANDRA de Marcoule à la connaissance de la marge crétacée rhodanienne. In: Actes des Journées scientifiques CNRS-ANDRA, Bagnols-sur-Cèze, 20-21 octobre 1997. Paris: EDP Sciences, pp. 63-91.

Ferry S. 2017. Summary on Mesozoic carbonate deposits of the Vocontian Trough (Sub-alpine Chains, SE France). In: Granier B, ed. Some Key Lower Cretaceous Sites in Drôme (SE France). Carnets de Géologie. Madrid, CG2017_B01, pp.9-42.

Föllmi KB. 1995. 160 m.y. record of marine sedimentary phosphorous burial: Coupling of climate and continental weathering under greenhouse and icehouse conditions. Geology 23: 859-862.

Föllmi KB. 2012. Early Cretaceous life, climate and anoxia. Cretaceous Research 35: 230-257

Föllmi KB, Bôle M, Jammet N, Froidevaux P, Godet A., Bodin S, et al. 2012. Bridging the Faraoni and Selli oceanic anoxic events: Late Hauterivian to early Aptian dysaerobic to anaerobic phases in the Tethys. Climate of the Past 8: 171-189.

Friedrich O, Reichelt K, Herrle JO, Lehmann J, Pross J, Hemleben C. 2003. Formation of the Late Aptian Niveau Fallot black shales in the
Vocontian Basin (SE France): Evidence from foraminifera, palynomorphs, and stable isotopes. Marine Micropaleontology 49: 65-85.

Friès G. 1987. Dynamique du basin subalpin méridional de l'Aptien au Cénomanien. Ph.D. Thesis, University of Paris 6, France. Mémoire des Sciences de la Terre ENS Mines Paris 4, 370 p.

Friès G., Parize O. 2003. Anatomy of ancient passive margin slope systems: Aptian gravity-driven deposition on the Vocontian palaomargin, western Alps, south-east France. Sedimentology 50 (6): 1231-1270.

Gambacorta G, Bottini C, Brumsack H-J, Schnetger B, Erba E. 2020. Major and trace element characterization of Oceanic Anoxic Event 1d (OAE1d): Insight from the Umbria-Marche Basin, central Italy. Chemical Geology, 119834.

Ghirardi J, Deconinck J-F, Pellenard P, Martinez M, Bruneau L, Amiotte-Suchet P, et al. 2014. Multi-proxy orbital chronology in the aftermath of the Aptian Oceanic Anoxic Event 1a: Palaeoceanographic implications (Serre Chaitieu section, Vocontian Basin, SE France). Newsletters on Stratigraphy 47(3): 247-262.

Goldberg K, Humayun M. 2010. The applicability of the chemical index of alteration as a paleoclimatic indicator: An example from the Permian of the Paraná Basin, Brazil. Palaeogeography, Palaeoclimatology, Palaeoecology 293: 175-183.

Godet A, Bodin S, Adatte T, Föllmi KB. 2008. Platform-induced claymineral fractionation along a northern Tethyan basin-platform transect: implications for the interpretation of Early Cretaceous climate change (Late Hauterivian-Early Aptian). Cretaceous Research 29: 830-847.

Graciansky PC de, Lemoine M. 1988. Early Cretaceous extensional tectonics in the southwestern French Alps: A consequence of North-Atlantic rifting during Tethyan spreading. Bull. Soc. géol. Fr. 4(5): 733-737.

Guérin S. 1981. Utilisation des foraminifères planctoniques et benthiques dans l'étude des paléo-environnements océaniques au Crétacé moyen: application au matériel des forages DSDP de l'Atlantique Nord et Sud. Comparaison avec la Téthys. Unpublished report, University of Nice, $198 \mathrm{p}$.

Haq BU. 2014. Cretaceous eustasy revisited. Global and Planetary Change 113: 44-58.

Haq BU, Hardenbol J, Vail PR. 1987. Chronology of fluctuating sea levels since the Triassic. Science 235: 1156-1167.

Hardenbol J, Thierry J, Farley MB, Jacquin T, Graciansky P-CD, Vail PR. 1998. Mesozoic and Cenozoic sequence chronostratigraphic framework of European basins. In: Graciansky P-CD, Hardenbol J, Jacquin T, Vail PR, eds. Mesozoic and Cenozoic Sequence Stratigraphy of European Basins. SEPM Special Publication 60, Charts, pp. 1-8.

Harris N. 2005. In: Harris NB, ed. The Deposition of OrganicCarbon-Rich Sediments: Models, Mechanisms and Consequences. Special Publications of SEPM, pp. 1-5.

Heimhofer U, Hochuli PA, Herrle JO, Andersen N, Weissert H. 2004. Absence of major vegetation and palaeoatmospheric $\mathrm{pCO}_{2}$ changes associated with oceanic anoxic event 1a (Early Aptian, SE France) Earth Planetary Science Letters 223: 303-318.

Heimhofer U, Hochuli PA, Herrle JO, Weissert H. 2006. Contrasting origins of Early Cretaceous black shales in the Vocontian basin: Evidence from palynological and calcareous nannofossil records. Palaeogeography, Palaeoclimatology, Palaeoecology 235: 93-109.

Herrle JO, Pross J, Friedrich O, Kößler P, Hemleben C. 2003. Forcing mechanisms for mid-Cretaceous black shale formation: Evidence from the Upper Aptian and Lower Albian of the Vocontian Basin (SE France). Palaeogeography, Palaeoclimatology, Palaeoecology 190: 399-426.

Herrle JO, Kößler P, Friedrich O, Erlenkeuser H, Hemleben C. 2004. High-resolution carbon isotope records of the Aptian to Lower 
Albian from SE France and the Mazagan Plateau (DSDP Site 545): A stratigraphic tool for paleoceanographic and paleobiologic reconstruction. Earth and Planetary Science Letters 218: 149-161.

Herrle JO, Kössler P, Bollmann J. 2010. Palaeoceanographic differences of early Late Aptian black shale events in the Vocontian Basin (SE France). Palaeogeography, Palaeoclimatology, Palaeoecology 297: 367-376.

Hu G, Hu W, Cao J, Yao S, Liu W, Zhou Z. 2014. Fluctuation of organic carbon isotopes of the Lower Cretaceous in coastal southeastern China: Terrestrial response to the Oceanic Anoxic Events (OAE1b). Palaeogeography, Palaeoclimatology, Palaeoecology 399: 352-362.

Huang C, Hinnov L, Fischer AG, Grippo A, Herbert T. 2010. Astronomical tuning of the Aptian Stage from Italian reference sections. Geology 38(10): 899-902.

Jenkyns HC. 2010. Geochemistry of oceanic anoxic events. Geochemistry, Geophysics, Geosystems 11(3): 1-30.

Joseph P, Beaudoin B, Friès G, Parize O. 1989. Les vallées sousmarines enregistrent au Crétacé inférieur le fonctionnement en blocs basculés du domaine vocontien. C R Acad Sci Paris 309: 1031-1038.

Kößler P, Herrle JO, Appel E, Erbacher J, Hemleben C. 2001. Magnetic records of climatic cycles from mid-cretaceous hemipelagic sediments of the Vocontian Basin, SE France. Cretaceous Research 22: 321-331.

Larson RL, Erba E. 1999. Onset of the mid-Cretaceous greenhouse in the Barremian-Aptian: Igneous events and the biological, sedimentary and geochemical responses. Paleoceanography 14: 663-678.

Leckie RM, Bralower TJ, Cashman R. 2002. Oceanic anoxic events and plankton evolution: Biotic response to tectonic forcing during the mid-Cretaceous. Paleoceanography 17.

Levert F, Ferry S. 1987. L'apport argileux dans le bassin mésozoïque subalpin. Quantification et problème d'altération de l'héritage. Géol. Alp, Mém. h.s. 13: 209-2013.

Levert J, Ferry S. 1988. Diagenèse argileuse complexe dans le Mésozoïque subalpin révélée par cartographie des proportions relatives d'argiles selon des niveaux isochrones. Bull. Soc. géol. Fr. 4: 1029-1038.

Malinverno A, Erba E, Herbert TD. 2010. Orbital tuning as an inverse problem: Chronology of the early Aptian oceanic anoxic event 1a (Selli level) in the Cismon APTICORE. Paleoceanography 25: PA2203.

Masse J-P, Bouaziz S, Amon EO, Baraboshin E, Tarkowski RA, Bergerat F, et al. 2000. Early Aptian (112-114 Ma), map 13. In: Dercourt J, Gaetani M, Vrielynck B, Barrier E, Biju-Duval B, Brunet MF, Cadet JP, Crasquin S, Sandulescu M, eds. Atlas Peri-Tethys: palaeoenvironmental maps, Explanatory notes. Paris, 268 p.

McCave IN, Manighetti B, Robinson SG. 1995. Sortable silt and fine sediment size/composition slicing: Parameters for palaeocurrent speed and palaeoceanography. Paleoceanography 10(3): 593-610.

McLennan SM. 2001. Relationships between the trace element composition of sedimentary rocks and upper continental crust. Geochemistry Geophysics Geosystems 2: 1021.

Menegatti AP, Weissert H, Brown RS, Tyson RV, Farrimond P, Strasser A, et al. 1998. High-resolution $813 \mathrm{C}$ stratigraphy through the early Aptian 'Livello Selli' of the Alpine Tethys. Paleoceanography 13(5): 530-545.

Montero-Serrano JC, Föllmi KB, Adatte T, Spangenberg JE, Tribovillard N, Fantasia A, et al. 2015. Continental weathering and redox conditions during the early Toarcian Oceanic Anoxic Event in the northwestern Tethys: Insight from the Posidonia Shale section in the Swiss Jura Mountains. Palaeogeography, Palaeoclimatology, Palaeoecology 429: 83-99.

Nesbitt HW, Young GM. 1982. Early Proterozoic climates and plate motions inferred from major element chemistry of lutites. Nature 299: 715-717.

O'Brien CL, Robinson SA, Pancost RD, Sinninghe Damsté JS, Schouten S, Lunt DJ, et al. 2017. Cretaceous sea-surface temperature evolution: Constraints from TEX86 and planktonic foraminiferal oxygen isotopes. Earth-Science Reviews 172: 224-247.

Okano K, Sawada K, Takashima R, Nishi H, Okada H. 2008. Further examples of archaeal-derived hydrocarbons in mid-Cretaceous oceanic anoxic event (OAE) 1b sediments. Organic Geochemistry 39: 1088-1091.

Pedersen TF, Calvert SE. 1990. Anoxia vs. Productivity: What controls the formation of organic-carbon-rich sediments and sedimentary rocks? AAPG Bulletin 74: 454-466.

Premoli Silva I, Erba E, Salvini G, Locatelli C, Verga D. 1999. Biotic changes in Cretaceous oceanic anoxic events of the Tethys. Journal of Foraminiferal Research 29: 352-370.

Riboulleau A, Bout-Roumazeilles V, Tribovillard N. 2014. Controls on detrital sedimentation in the Cariaco Basin during the last climatic cycle: Insight from clay minerals. Quaternary Science Reviews 94: 62-73.

Rubino J-L. 1989. Introductory remarks on Upper Aptian to Albian siliciclastic/carbonate depositional sequences. In: Ferry S., Rubino JL, eds. Mesozoic Eustacyon Western Tethyan Margins. Post-Meeting Field Trip in the "Vocontian Trough". ASF, Publ. Spéc. 12: 28-45.

Sabatino N, Coccioni R, Salvagio Manta D, Baudin F, Vallefuoco M, Traina A, et al. 2015. High-resolution chemostratigraphy of the late Aptian-early Albian oceanic anoxic event (OAE1b) from the Poggio le Guaine section (Umbria-Marche Basin, central Italy). Palaeogeography, Palaeoclimatology, Palaeoecology 426: 319-333.

Sabatino N, Ferraro S, Coccioni R, Bonsignore M, Del M, Tancredi V, et al. 2018. Mercury anomalies in upper Aptian-lower Albian sediments from the Tethys realm. Palaeogeography, Palaeoclimatology, Palaeoecology 495: 163-170.

Sageman BB, Murphy AE, Werne JP, Ver Straeten CA, Hollander DJ, Lyons TW. 2003. A tale of shales: the relative roles of production, decomposition, and dilution in the accumulation of organic-rich strata, Middle-Upper Devonian, Appalachian basin. Chemical Geology 195: 229-273.

Sanfourche J, Baudin F. 2001. La genèse des évènements anoxiques de la période moyenne du Crétacé. Examen de l'hypothèse du mécromictisme océanique. Ann. Soc Geol. du Nord $8\left(2^{\mathrm{e}}\right.$ série): $107-119$.

Schlanger SO, Jenkyns HC. 1976. Cretaceous oceanic anoxic event: causes and consequences. Geol. Mijnbouw 55: 179-188.

Sperazza M, Moore JN, Hendrix MS. 2004. High-resolution particle size analysis of naturally occurring very Fine-Grained sediment through laser diffractometry. Journal of Sedimentary Research 74 (5): 736-743.

Stein M, Föllmi KB, Westermann S, Godet A, Adatte T, Matera V, et al. 2011. Progressive palaeoenvironmental change during the Late Barremian-Early Aptian as prelude to Oceanic Anoxic Event 1a: Evidence from the Gorgo a Cerbara section (Umbria-Marche basin, central Italy). Palaeogeography, Palaeoclimatology, Palaeoecology 302: 396-406.

Trabucho Alexandre J, Tuenter E, Henstra GA, van der Zwan KJ, van de Wal RSW, Dijkstra HA, et al. 2010. The mid-Cretaceous North Atlantic nutrient trap: Black shales and OAEs. Paleoceanography 25: PA4201.

Trabucho Alexandre JT, Van Gilst RI, Rodríguez-López JP, De Boer PL. 2011. The sedimentary expression of oceanic anoxic event $1 \mathrm{~b}$ in the North Atlantic. Sedimentology 58: 1217-1246. 
Trentesaux A, Recourt P, Bout-Roumazeilles V, Tribovillard N. 2001. Carbonate grain- size distribution in hemipelagic sediments from a laser particle sizer. Journal of Sedimentary Research 71: 858-862.

Tribovillard NP. 1989. Sédimentation rythmique dans les Marnes Bleues de l'Aptien-Albien du bassin vocontien (France Sud-Est). In: Cotillon $\mathrm{P}$, ed. Les événements de la partie moyenne du Crétacé, Géobios Spec. Publ. 11: 213-224.

Tribovillard NP, Gorin GE. 1991. Organic facies of the early Albian Niveau Paquier, a key black shales horizon of the Marnes Bleues formation in the Vocontian Trough (Subalpine Ranges, SE France). Palaeogeography, Palaeoclimatology, Palaeoecology 85: 227-237.

Tribovillard N, Algeo T, Lyons TW, Riboulleau A. 2006. Trace metals as paleoredox and paleoproductivity proxies: an update. Chemical Geology 232: 12-32.

Tyson RV. 2001. Sedimentation rate, dilution, preservation and total organic carbon: some results of a modelling study. Organic Geochemistry 32: 333-339.
Tyson RV. 2005. The 'productivity versus preservation' controversy: cause, flaws and resolution. In: Harris NB, ed. The Deposition of Organic-carbon-rich Sediments: Models, Mechanisms and Consequences. SEPM Spec Publ 82: 17-33.

Vickers ML, Price GD, Jerrett RM, Watkinson M. 2016. Stratigraphic and geochemical expression of Barremian-Aptian global climate change in Arctic Svalbard. Geosphere 12: 1594-1605.

Von Eynatten H, Barcelo-Vidal C, Pawlowsky-Glahn V. 2003. Modelling compositional change: the example of chemical weathering of granitoid rocks. Mathematical Geology 35: 231-251.

Weissert H. 1990. Siliciclastics in the Early Cretaceous Tethys and North Atlantic oceans: Documents of periodic greenhouse climate conditions. Memorie - Società Geologica Italiana 44: 59-69.

Westermann S, Stein M, Matera V, Fiet N, Fleitmann D, Adatte T, et al. 2013. Rapid changes in the redox conditions of the western Tethys Ocean during the early Aptian oceanic anoxic event Geochimica et Cosmochimica Acta 121: 467-486.

Cite this article as: Caillaud A, Quijada M, Hlohowskyj SR, Chappaz A, Bout-Roumazeilles V, Reynaud J-Y, Riboulleau A, Baudin F, Adatte T, Ferry J-N, Tribovillard N. 2022. Assessing controls on organic matter enrichments in hemipelagic marls of the Aptian-Lower Albian Blue Marls of the Vocontian Basin (France): an unexpected variability observed from multiple "organic-rich" levels, $B S G F$ - Earth Sciences Bulletin 193: 2. 